\title{
Toward poly(aminophthalimide), structures of dimers and trimers
}

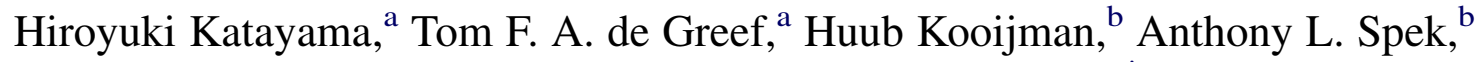 \\ Jef A. J. M. Vekemans ${ }^{a}$ and E. W. Meijer ${ }^{a}, *$ \\ ${ }^{a}$ Laboratory of Macromolecular and Organic Chemistry, Department of Chemistry, Eindhoven University of Technology, \\ PO Box 513, 5600 MB Eindhoven, The Netherlands \\ ${ }^{\mathrm{b}}$ Bijvoet Center for Biomolecular Research, Crystal and Structural Chemistry, Utrecht University, Padualaan 8 , \\ 3584 CH Utrecht, The Netherlands
}

Received 17 January 2007; revised 30 March 2007; accepted 2 April 2007

Available online 6 April 2007

\begin{abstract}
Poly(aminophthalimide) (PAP) dimers and trimers have been synthesized by palladium-catalyzed cross-coupling reactions of 3-aminophthalimides with 3-chloro- and 3,6-dichlorophthalimide, respectively. When $\mathrm{Pd}(\mathrm{OAc})_{2}$, XPhos (2-dicyclohexylphosphino$2^{\prime}, 4^{\prime}, 6^{\prime}$-triisopropylbiphenyl), and $\mathrm{K}_{3} \mathrm{PO}_{4}$ are used, the $\mathrm{C}-\mathrm{N}$ bond-forming reactions proceed quantitatively. The structures of those oligomers are examined by experimental and theoretical techniques including NMR, IR, single-crystal X-ray diffraction, and DFT calculations. The strong preference for cisoid structure of the diphthalimidylamine unit bearing a bifurcate hydrogen bonding is disclosed. Therefore, the aminophthalimide backbone is a highly promising candidate for the construction of a dynamically ordered helical structure.
\end{abstract}

(C) 2007 Elsevier Ltd. All rights reserved.

\section{Introduction}

The design of synthetic oligomers characterized by ordered solution conformations has recently attracted intense interest from different scientific areas. Considerable effort from numerous groups ${ }^{1}$ has resulted in a wealth of synthetic non-natural oligomers capable of adopting one preferred backbone conformation out of a large number of accessible conformations. Foldamers ${ }^{2}$ represent a subclass of oligomers in which the restricted backbone conformation is caused by non-covalent interactions between adjacent and nonadjacent monomeric units. Hydrogen bonding, ${ }^{3-9}$ solvophobic, ${ }^{10-14}$ aromatic donor-acceptor, ${ }^{15,16}$ metal-ligand, ${ }^{17}$ and anion-hydrogen bond ${ }^{18}$ interactions have all been utilized as driving forces for the cooperative transition of random coiled backbones into well defined helical architectures. ${ }^{19}$ Due to their compact and ordered conformations, foldamers have found use as protein mimics competing with a variety of protein-protein, ${ }^{20}$ protein-membrane,${ }^{21}$ and protein-sugar ${ }^{22}$ interactions. Furthermore, foldamers present an inner-void, which can be used to create stimuli-responsive materials upon binding of a specific guest with an affinity for the interior. Examples are binding of mercury ions to helical oligomeric cholates ${ }^{23}$ and the induction of helicity in oligo(meta-ethynylpyridine)s upon binding of saccharides. ${ }^{24}$ From a fundamental point of view, the intrinsic folding dynamics ${ }^{25}$ of these molecules can provide insight into the

\footnotetext{
* Corresponding author. E-mail: e.w.meijer@tue.nl
}

more complex folding behavior of proteins as foldamers are composed of a single monomer.

Recently, we reported a new class of poly(ureidophthalimides) (PUP, 1) illustrated in Figure 1, which was shown to fold in apolar and polar media ${ }^{25-27}$ depending on the nature of the $\mathrm{R}^{*}$ group. The $\mathrm{NH}$-groups of the ureas, which are positioned at the 3,6-positions of phthalimide ring, preferentially adopt a conformation in which intramolecular hydrogen bonding of the $\mathrm{NH}$ protons with the adjacent imide oxygens is operational. In case of a cisoid urea conformation, the consecutive monomer units lead to a curvature in the backbone and this may induce folding, probably with the aid of interlayer $\pi-\pi$ stacking. Furthermore, a small perturbation by chiral groups $\left(\mathrm{R}^{*}\right)$ on the periphery ${ }^{28}$ can bias the twist sense of the helical structure.

In order to gain more insight into the thermodynamics and kinetics of folding of phthalimide based foldamers we have turned our focus on the design of a new foldamer in which the conformational lock of the subunit, caused by the strong intramolecular hydrogen bond, is loosened as compared to our previous PUP foldamer. By loosening the conformational lock we hope to achieve that the number of torsionally accessible conformations of a given oligomer will increase slightly, thereby increasing the effect of configurational entropy on the folding process. Changes in the configurational entropy of the folding process will lead to a foldamer with a significantly different free energy landscape $^{29}$ as compared to PUP foldamers. Moreover, by 


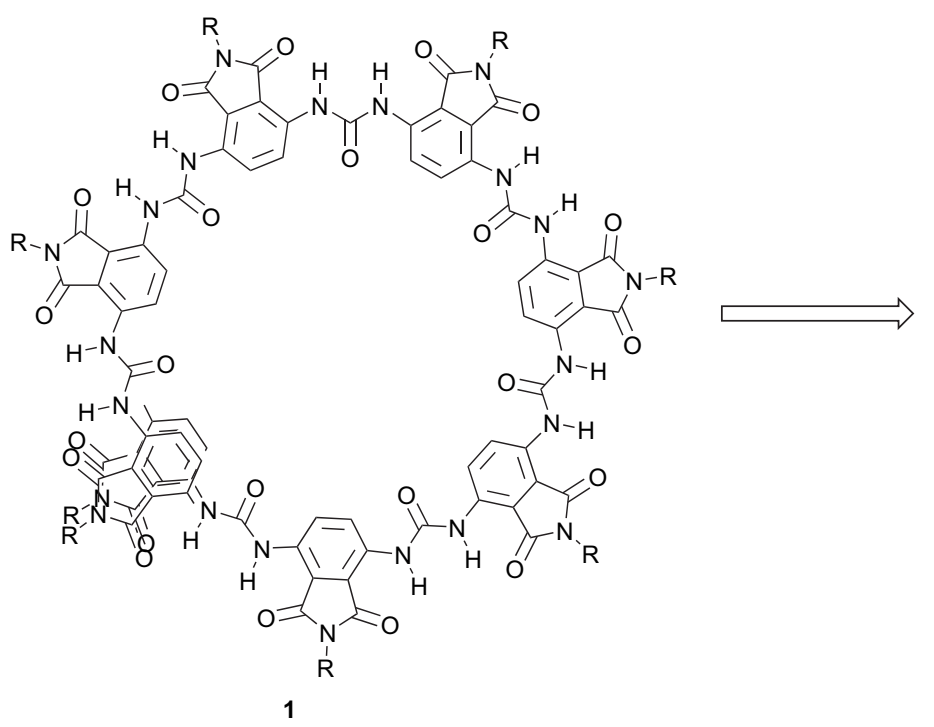<smiles>[R7]N1C(=O)c2c(N)ccc(N)c2C1=O</smiles>

Figure 1. Tentative helical structure of poly(ureidophthalimide) (PUP) foldamer 1 obtained by polymerization of the corresponding di-isocyanato and di-amino phthalimide monomers. The number of units per helical turn has been estimated to be $>7 .^{25,27}$

focusing our attention on stronger interactions between nonadjacent units, oligomers with a true cooperative transition between extended and folded conformations are envisioned.

We therefore turned our attention on the introduction of amine $(\mathrm{NH})$ linkage instead of a urea linkage. As shown by poly(aminophthalimide) (PAP, 2) in Figure 2, the amine hydrogen would form a hydrogen bond in a six-membered ring giving rise to a curved backbone, in a way similar to the ureidophthalimide. It is hypothesized that the resulting NH proton will still be a good proton donor as the electron accepting carbonyl substituents will increase its acidity considerably.

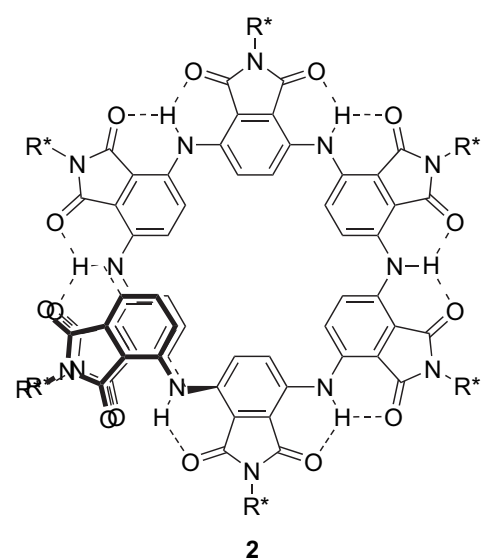

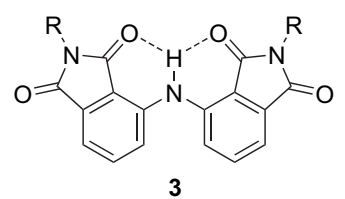

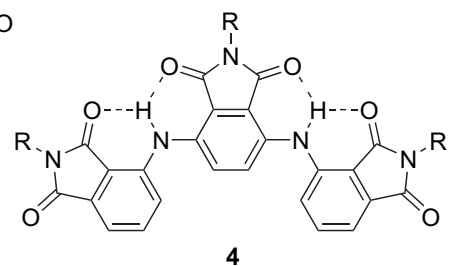

Figure 2. Tentative helical structure of poly(aminophthalimide) (PAP) foldamer 2 and structures of dimer 3 and trimer 4.
The resulting helix will display a smaller inner-void due to the decrease in the number of linking atoms as compared to the ureido counterpart. Presumably, steric repulsion between the ortho protons may occur giving rise to a smaller number of units per helix turn. This may induce stronger interactions between non-adjacent units within a given oligomer, for example, by an increase in the strength of $\pi-\pi$ interactions due to a shorter distance between the overlapping units in the folded conformation.

Furthermore, due to its polyaniline-based backbone, these structures can serve as $\pi$-conjugated polymers with appealing electronic properties. ${ }^{30}$ By incorporating electron-donating monomers bearing hydrogen bond acceptor units, low band-gap polymers with highly ordered structures can be envisioned. ${ }^{31}$

Palladium-catalyzed C-N bond formation has been envisaged as one of the most practical and straightforward ways to construct a phthalimide-amine sequence in $\mathbf{2}$. This methodology has become a widely used practical method of synthesizing diarylamines. ${ }^{32,33}$ As for the aminophthalimide synthesis, Buchwald and Hennessy reported a synthetic route to 4,5-dianilinophthalimides that employs the palladium-catalyzed amination as the key bond-forming step. ${ }^{34}$ More recently, catalytic polycondensation between 3,6-dibromophthalimide and 1,4-phenylenediamine to afford a hybrid polymer of polyaniline and phthalimide dyes was reported by Müllen and co-workers. ${ }^{35}$

In this paper, we demonstrate the $\mathrm{Pd}(\mathrm{OAc})_{2} / \mathrm{XPhos}$-catalyzed system (XPhos=2-dicyclohexylphosphino-2', $4^{\prime}, 6^{\prime}$ triisopropylbiphenyl), which was originally developed by the Buchwald group, to be effective in synthesizing 3,6linked aminophthalimide scaffolds by illustrating the segmental PAP dimer (3) and trimer (4) formations. The experimental and theoretical studies on the structures of those oligomers show that they nicely fit into the designed architecture of $\mathbf{2}$. 


\section{Results and discussion}

\subsection{Synthesis of 3-aminophthalimides}

Three kinds of 3-amino- $N$-arylphthalimides 9a-c for the building blocks of $\mathbf{3}$ and $\mathbf{4}$ were prepared in four steps according to Scheme 1. Dehydration of 3-nitrophthalic acid followed by catalytic reduction/acetylation of the resulting nitro compound $\mathbf{5}$ yielded 3-acetylaminophthalic anhydride (6) ${ }^{36}$ Subsequent reaction of $\mathbf{6}$ with primary aromatic amines $7 \mathbf{a}-\mathbf{c}$ in acetic acid or 1,4-dioxane at $100^{\circ} \mathrm{C}$ afforded 3 -acetylamino- $N$-arylphthalimides $\mathbf{8 a}-\mathbf{c}$, which were then treated with aq $\mathrm{HCl}$ to give $9 \mathbf{a}-\mathbf{c}$ in a total yield of $46-$ $84 \%$ in two steps. Compounds $\mathbf{9 a - c}$ were obtained as yellow crystalline solids that are air-stable and can be safely stored under ambient conditions for months. Condensation of $\mathbf{5}$ with 7 followed by nitro group reduction could also provide 9 in a one step less procedure. In this case, however, lower appreciated reactivity of $\mathbf{5}$ toward the imidation reduced the overall yields, especially for gallic derivative $9 \mathbf{c}^{26}$

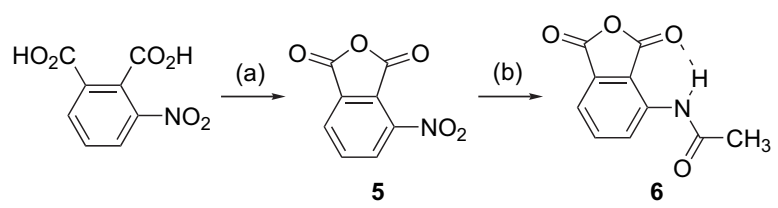

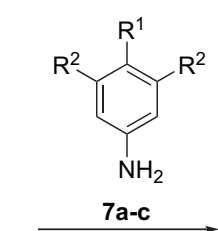

(c)

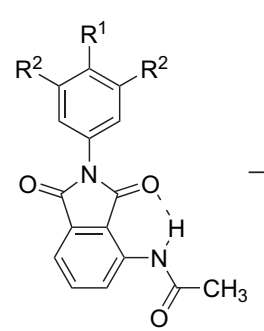

8a: $79 \%$

8b: $68 \%$

8 c: $98 \%$ $\stackrel{(d)}{ }$

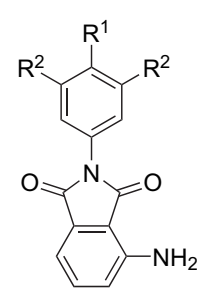

9a: $58 \%$

9b: $76 \%$

Scheme 1. Synthesis of 3-amino- $N$-arylphthalimides (9a-c). (a) $\mathrm{Ac}_{2} \mathrm{O}$, reflux. (b) (i) $\mathrm{H}_{2}, \mathrm{Pd} / \mathrm{C}$, (ii) $\mathrm{Ac}_{2} \mathrm{O}, 100^{\circ} \mathrm{C}$. (c) $\mathrm{AcOH}$ or 1,4-dioxane, $100{ }^{\circ} \mathrm{C}$. (d) (i) aq HCl, 1,4-dioxane, $100{ }^{\circ} \mathrm{C}$, (ii) $\mathrm{NH}_{3}$ (aq).

\subsection{Synthesis of phthalimidyl halides and triflates}

To systematically investigate the effect of various phthalimide electrophiles on the $\mathrm{C}-\mathrm{N}$ coupling, a series of the halides and triflates were synthesized. 3-Chloro- $(\mathbf{1 0 a}-\mathbf{c})$, 3-iodo- (11a,b), and 3,6-dichlorophthalimides (12a-c) were readily accessible from the corresponding anhydrides (Eq. 1). On the other hand, the same strategy was not applied to synthesize 3,6-diiodophthalimides (17) because of the inaccessibility of the starting anhydride. For example, attempts to prepare such anhydride by direct or palladium-catalyzed iodination of phthalic anhydride and permanganate oxidation of 3,6-diiodo-o-xylene were all unsuccessful. A Diels-Alder approach was then examined (Eq. 2). $N$-Arylmaleimides $\mathbf{1 3 b}, \mathbf{c}$ were prepared by a two-step imidation of maleic anhydride with $\mathbf{7 b}, \mathbf{c}$ according to the literature. ${ }^{37}$ 2,5-Diiodothiophene-1,1-dioxide (15) was selected as a diene substrate because elimination of sulfur dioxide from the Diels-Alder adduct and the subsequent aerobic oxidation to aromatize

the product were highly expected to take place spontaneously after the $[4+2]$ cycloaddition. ${ }^{38}$ Indeed, heating a mixture of 15 and $13 \mathrm{~b}$ or $13 \mathrm{c}$ in DMF at $130{ }^{\circ} \mathrm{C}$ for $18-22 \mathrm{~h}$ gave the corresponding 3,6-diiodophthalimides $\mathbf{1 7} \mathbf{b}, \mathbf{c}$, albeit in rather low yields. 3,6-Dibromo- $N$-trialkoxyphenylphthalimide 16c could be also prepared by this method. Finally, synthesis of ditriflates 19 was accomplished by imidation of 3,6-dihydroxyphthalic anhydride followed by esterification of the resulting dihydroxyphthalimide $\mathbf{1 8}$ with triflic anhydride (Scheme 2). Compounds 19a,b were substantially moisture-stable allowing the purification by silica gel column chromatography.
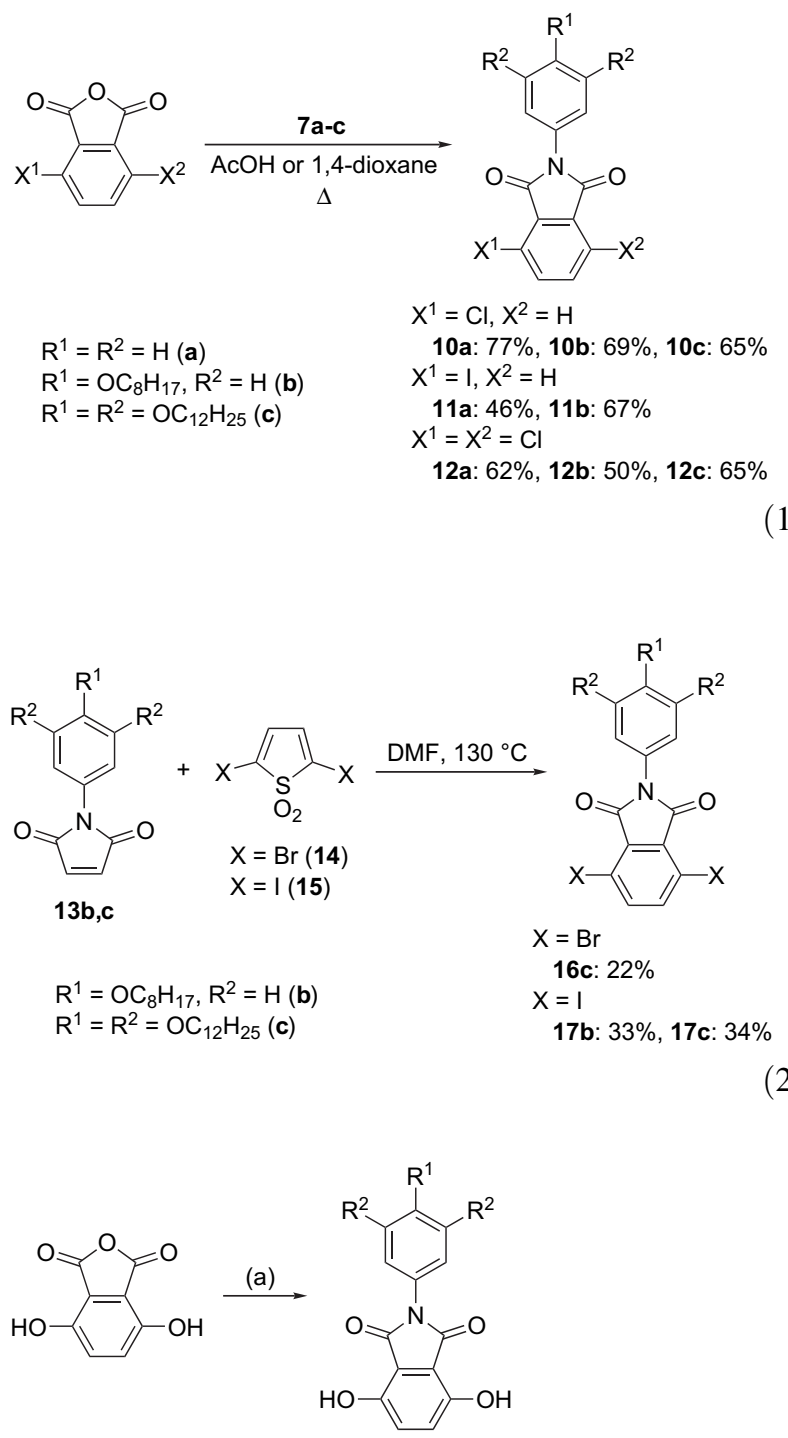

18a: $73 \%, 18 b: 60 \%$

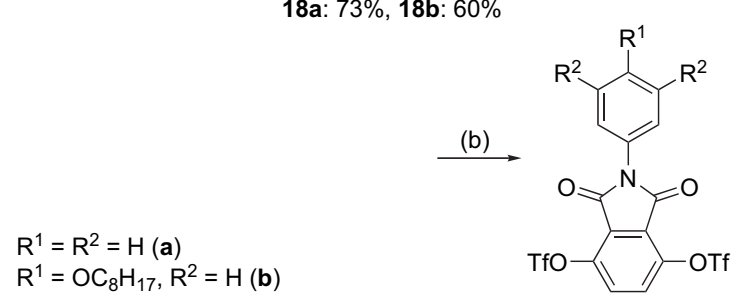

19a: $85 \%, 19 b: 90 \%$

Scheme 2. Synthesis of phthalimidyl triflates (19a,b). (a) 7a,b, AcOH, $100{ }^{\circ} \mathrm{C}$. (b) $\mathrm{Tf}_{2} \mathrm{O}$, pyridine, toluene, $0{ }^{\circ} \mathrm{C}$ to $\mathrm{rt}$. 


\subsection{Palladium-catalyzed $\mathrm{C}-\mathrm{N}$ coupling reaction}

Taking the generally accepted reactivity order of cross-coupling substrates into account, an initial attempt to synthesize PAP dimer 3 was made on 3-iodophthalimide 11 (Eq. 3). The reaction of $\mathbf{1 1 b}$ with an equimolar amount of 3-aminophthalimide $9 \mathrm{~b}$ completed at $100{ }^{\circ} \mathrm{C}$ within $6 \mathrm{~h}$ in the presence of $\operatorname{Pd}(\mathrm{dba})_{2}$ (2 mol \%), Xantphos (4,5-bis(diphenylphosphino)9,9-dimethylxanthene) (4 mol \%), and $\mathrm{Cs}_{2} \mathrm{CO}_{3}$ (1.5 equiv) to give an orange solid of PAP dimer bearing octyloxy tails $\mathbf{3 b}$ in $85 \%$ isolated yield. Under similar conditions PAP dimer 3a was obtained as a yellow solid in $91 \%$ yield.

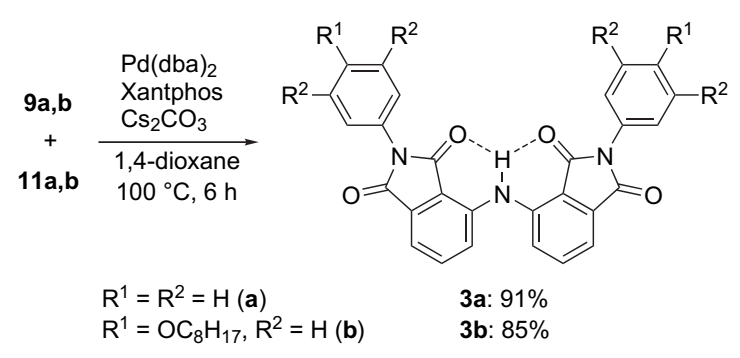

Gratified with these results, we next performed the reaction of $\mathbf{9 b}$ with 3,6-diiodophthalimide $\mathbf{1 7} \mathbf{b}$ with the aim of synthesizing PAP trimer $\mathbf{4 b}$. However, ${ }^{1} \mathrm{H}$ NMR and MALDITOF-MS analyses of the crude reaction mixture indicated the formation of only $\sim 20 \% \mathbf{4 b}$ along with a number of unidentified products. The reactions using 3,6-ditriflates 19a,b gave somewhat better results (45\% yield for $\mathbf{4 a}, 30 \%$ yield for $\mathbf{4 b}$ ), but were still unsatisfactory when considering future higher oligomer synthesis. To establish more effective conditions, the reactions between 9c and 3,6-dihalophthalimides $(\mathbf{1 2 c}, 16 c, 17 c)$ were examined with varying palladium source, ligand, and base (Table 1). The use of XPhos instead of Xantphos slightly improved the yield of $\mathbf{4 c}$ (runs 1 and 2). Regarding the effect of the sort of halogen atoms in 3,6-dihalophthalimides, interestingly, the yield increased in the order 17c $(\mathrm{X}=\mathrm{I})<\mathbf{1 6 c}(\mathrm{X}=\mathrm{Br})<\mathbf{1 2 c}(\mathrm{X}=\mathrm{Cl})$ (runs 24 ), which is rather unusual in cross-coupling chemistry. It should be mentioned that no significant by-product was detected in the reaction of dichlorophthalimide 12c (run 4). Potassium phosphate was the base of choice among those tested (runs 4-6). A dramatic rate increase was observed when the palladium source $\mathrm{Pd}_{2}(\mathrm{dba})_{3}$ was replaced by $\mathrm{Pd}(\mathrm{OAc})_{2}$ (run 7). In this case the $\mathrm{C}-\mathrm{N}$ bond formation proceeded quantitatively, and the trimer $\mathbf{4 c}$ was isolated as an orange sticky solid in $97 \%$ yield.

With these optimized conditions ( $\left.\mathrm{Pd}(\mathrm{OAc})_{2} / \mathrm{XPhos} / \mathrm{K}_{3} \mathrm{PO}_{4}\right)$ in hand, the syntheses of PAP dimers $\mathbf{3 a}-\mathbf{c}$ and PAP trimers $\mathbf{4 a}, \mathbf{b}$ were re-examined using chlorophthalimides $10 \mathbf{a}-\mathbf{c}$ and $\mathbf{1 2 a}, \mathbf{b}$, respectively, instead of the corresponding iodide $\mathbf{9}$. Consequently, nearly quantitative conversion was attained in each case, giving the desired PAP oligomers in $91 \%$ isolated yield.

\subsection{Structural identification of PAP dimers 3 and trimers 4}

All the PAP oligomers thus obtained were characterized by ${ }^{1} \mathrm{H}$ and ${ }^{13} \mathrm{C}$ NMR, IR, MALDI-TOF-MS, and elemental
Table 1. Synthesis of PAP trimer $4 c^{a}$

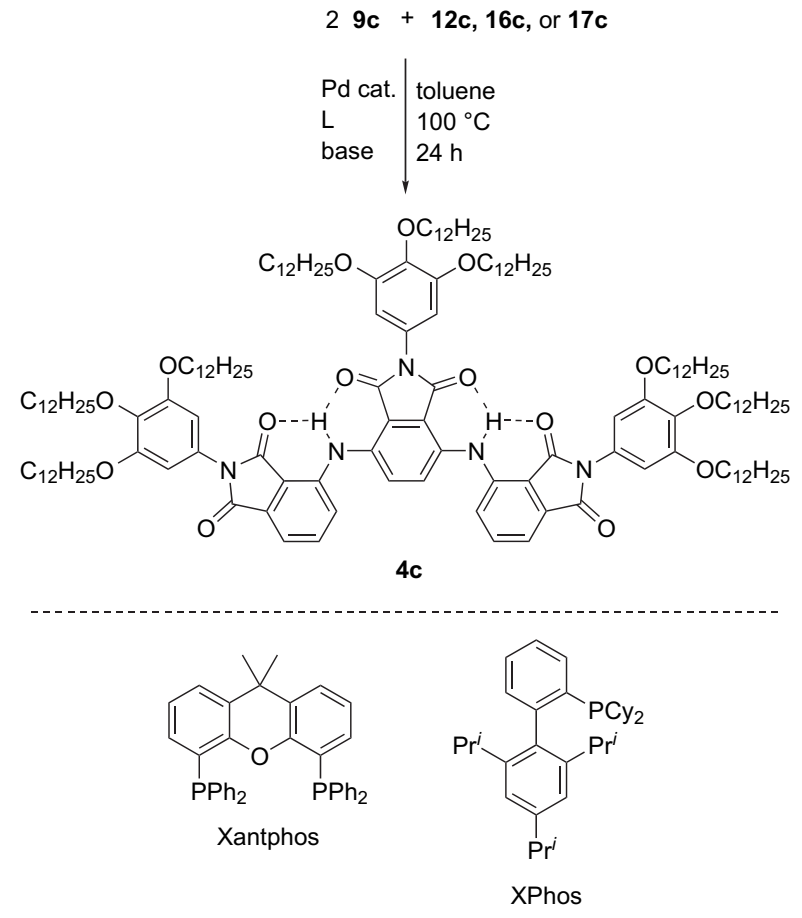

\begin{tabular}{llllll}
\hline $\begin{array}{l}\text { Run } \\
\text { 3,6-Dihalophthalimide } \\
(\mathrm{X})\end{array}$ & $\mathrm{Pd}$ cat. & $\mathrm{L}$ & Base & Yield $^{\mathrm{b}}(\%)$ \\
\hline $1^{\mathrm{c}}$ & $\mathbf{1 7 c}(\mathrm{I})$ & $\mathrm{Pd}_{2}(\mathrm{dba})_{3}$ & Xantphos & $\mathrm{Cs}_{2} \mathrm{CO}_{3}$ & 27 \\
2 & $\mathbf{1 7 c}(\mathrm{I})$ & $\mathrm{Pd}_{2}(\mathrm{dba})_{3}$ & XPhos & $\mathrm{K}_{3} \mathrm{PO}_{4}$ & 35 \\
3 & $\mathbf{1 6 c}(\mathrm{Br})$ & $\mathrm{Pd}_{2}(\mathrm{dba})_{3}$ & XPhos & $\mathrm{K}_{3} \mathrm{PO}_{4}$ & 43 \\
4 & $\mathbf{1 2 c}(\mathrm{Cl})$ & $\mathrm{Pd}_{2}(\mathrm{dba})_{3}$ & XPhos & $\mathrm{K}_{3} \mathrm{PO}_{4}$ & $76(59)$ \\
5 & $\mathbf{1 2 c}(\mathrm{Cl})$ & $\mathrm{Pd}_{2}(\mathrm{dba})_{3}$ & XPhos & $\mathrm{Cs}_{2} \mathrm{CO}_{3}$ & 64 \\
6 & $\mathbf{1 2 c}(\mathrm{Cl})$ & $\mathrm{Pd}_{2}(\mathrm{dba})_{3}$ & XPhos & $\mathrm{K}_{2} \mathrm{CO}_{3}$ & 17 \\
7 & $\mathbf{1 2 c}(\mathrm{Cl})$ & $\mathrm{Pd}(\mathrm{OAc})_{2}$ & XPhos & $\mathrm{K}_{3} \mathrm{PO}_{4}$ & $>99(97)$ \\
\hline
\end{tabular}

a All reactions were carried out with 3,6-dihalophthalimide $(25 \mathrm{mM}), 9 c$ ( 2.2 equiv), $\mathrm{Pd}$ cat. ( $1-2 \mathrm{~mol} \%), \mathrm{Pd} / \mathrm{L}=1 / 2$, and base ( 3 equiv) in toluene at $100{ }^{\circ} \mathrm{C}$ for $24 \mathrm{~h}$, unless otherwise noted.

b NMR yield using $\mathrm{C}_{6} \mathrm{Me}_{6}$ as an internal standard. The number in parentheses is isolated yield after column chromatography.

c The reaction was run in 1,4-dioxane.

analysis. Furthermore, because PAP trimer $\mathbf{4 c}$ is the longest monodisperse oligomer in our hands, all resonances were unambiguously assigned by ${ }^{1} \mathrm{H}$ and ${ }^{13} \mathrm{C}$ NMR spectroscopies with ${ }^{1} \mathrm{H}-{ }^{1} \mathrm{H}$ correlation spectroscopy (gCOSY, TOCSY) and gradient enhanced heteronuclear multiple quantum coherence (gHMQC). The key spectroscopic features are summarized in Table 2 . The ${ }^{1} \mathrm{H}$ signals of phthalimide ring protons $\left(\mathrm{H}^{\alpha-\gamma}\right)$ were assigned based on the mutual coupling patterns and constants. Figure 3 depicts the expanded ${ }^{1} \mathrm{H}$ NMR spectra of $\mathbf{3 c}$ and $\mathbf{4 c}$ in $\mathrm{CDCl}_{3}$. Also shown are the spectra of $\mathbf{8 c}, 9 \mathbf{c}$, and PUP dimer $\mathbf{2 0 b}$, which has been prepared by catalytic $\mathrm{C}-\mathrm{N}$ coupling of $\mathbf{1 1 b}$ and urea, ${ }^{39}$ for comparison. While the $\mathrm{NH}$ proton signal of amine $9 \mathrm{c}$ is observed at ordinary position (5.30 ppm), those of PAP, PUP, and acetylamino compounds appears considerably downfield $(>9.3 \mathrm{ppm})$. This shift is attributed to intramolecular hydrogen bonding with the imide oxygen. Appearance of the $\mathrm{NH}$ proton signal of $\mathbf{3 c}$ and $\mathbf{4 c}$ at a more downfield position than that of $\mathbf{2 0 b}$ presumably implies the bifurcate nature of the hydrogen bonding of PAP compounds. The intramolecular fashion was demonstrated by the fact that the signals of $\mathrm{NH}$ and $\mathrm{H}^{\alpha-\gamma}$ were independent on sample concentration 
Table 2. Selected ${ }^{1} \mathrm{H}$ NMR and IR data for $\mathbf{3 a}-\mathbf{c}$ and $\mathbf{4 a - c}$<smiles>[Y]c1cccc(-n2c(=O)n([R])c(=O)c3c([Y])cccc32)c1Cl</smiles>

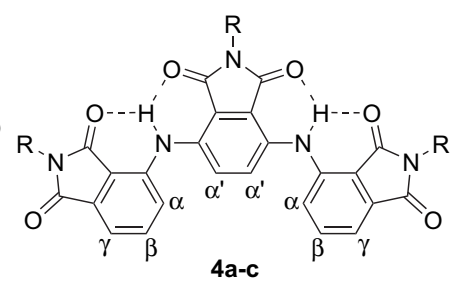

\begin{tabular}{|c|c|c|c|c|c|c|}
\hline \multirow[t]{2}{*}{ Compound } & \multicolumn{5}{|c|}{${ }^{1} \mathrm{H} \mathrm{NMR}^{\mathrm{a}}$} & \multirow{2}{*}{$\frac{\mathrm{IR}^{\mathrm{b}}}{\nu_{\mathrm{NH}}}$} \\
\hline & $\mathrm{NH}$ & $\mathrm{H}^{\alpha^{\prime}}$ & $\mathrm{H}^{\alpha}$ & $\mathrm{H}^{\beta}$ & $\mathrm{H}^{\gamma}$ & \\
\hline $3 \mathbf{a}$ & 10.15 & & 7.86 & 7.71 & 7.54 & 3303 \\
\hline $3 \mathbf{b}$ & 10.11 & & 7.84 & 7.70 & 7.53 & 3282 \\
\hline $3 c$ & 10.00 & & 7.83 & 7.69 & 7.51 & 3293 \\
\hline $4 \mathbf{a}$ & 10.00 & 7.87 & 7.78 & 7.69 & 7.51 & 3298 \\
\hline $4 b$ & 9.80 & 7.75 & 7.64 & 7.53 & 7.36 & 3314 \\
\hline 4c & 9.85 & 7.83 & 7.75 & 7.67 & 7.49 & 3317 \\
\hline
\end{tabular}

a $\mathrm{In} \mathrm{CDCl}_{3}$ at $20^{\circ} \mathrm{C}$.

b Neat.

in the range from 0.2 to $25 \mathrm{mM}$ in $\mathrm{CDCl}_{3}$. The signal of $\mathrm{H}^{\alpha}$ protons of phthalimide ring in $\mathbf{8 c}$ and $\mathbf{2 0 b}$ shows a remarkably downfield shift (8.8-8.7 ppm) compared to the other ring protons (7.8-7.6 ppm), which is due to the anisotropic deshielding effect by the proximal carbonyl double bond.

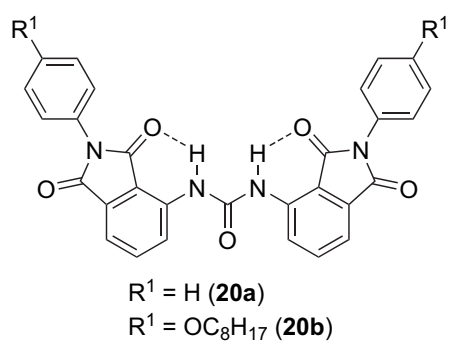

2D NOESY experiments on PAP trimer $\mathbf{4 c}$ in $\mathrm{CDCl}_{3}$ were performed to confirm its crescent shape in solution. A strong NOE contact ${ }^{40}$ (Fig. 3) can be observed between $\mathrm{H}_{\alpha^{\prime}}$ and $\mathrm{H}_{\alpha}$

(a)

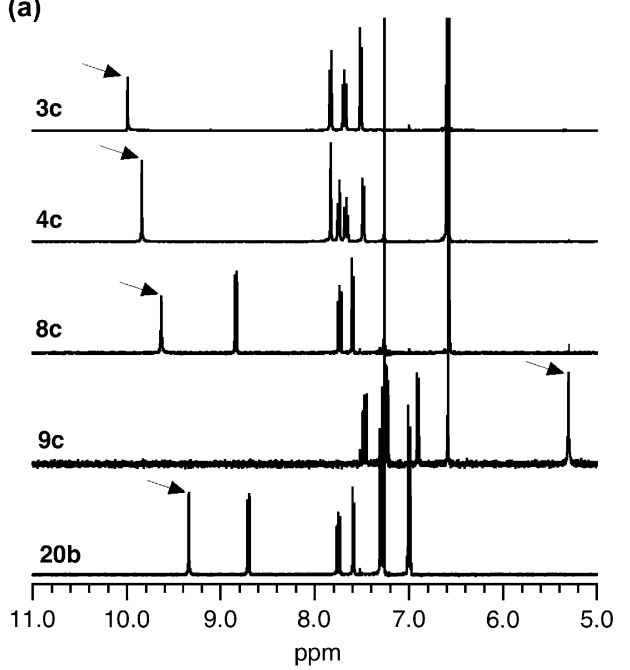

indicating that the trimer adopts the expected syn conformation in solution. Furthermore, a weak NOE contact is observed between the $\mathrm{NH}$ proton and $\mathrm{H}_{\alpha^{\prime}}$ proton consistent with the larger distance between these two protons in the syn conformation. In combination with the large downfield shift of the NH proton as compared to the $\mathrm{NH}$ resonances in other aniline oligomers bearing electron withdrawing groups, ${ }^{41}$ these results imply the existence of an intramolecularly H-bonded six-membered ring and the preferred synsyn conformation adopted by the phthalimide groups.

To evaluate the extent of hydrogen bonding of PAP and PUP compounds, variable temperature ${ }^{1} \mathrm{H}$ NMR measurements on $\mathbf{3 b}$ and $\mathbf{2 0 b}$ in 1,1,2,2-tetrachloroethane- $d_{2}$ were performed. Upfield shifts of the $\mathrm{NH}$ and $\mathrm{H}^{\alpha-\gamma}$ proton resonances were observed with increasing temperature in each case, whereas other signals such as $\mathrm{OCH}_{2}$ resonances remained unchanged. This result implies that the extent of hydrogen bonding is reduced at higher temperatures due to the increased population of less favored conformers. Figure 4 shows the chemical shifts of the $\mathrm{NH}$ and $\mathrm{H}^{\alpha}$ proton signals as a function of temperature. The changes in $\Delta \delta / \Delta T$ for $\mathbf{3 b}$ $\left(2.2 \times 10^{-3}\right.$ for $\mathrm{NH}, 1.1 \times 10^{-3}$ for $\left.\mathrm{H}^{\alpha}\right)$ are larger than those for $20 \mathrm{~b}\left(1.1 \times 10^{-3}\right.$ for $\mathrm{NH}, 0.56 \times 10^{-3}$ for $\left.\mathrm{H}^{\alpha}\right)$. Based on these values it can be concluded that in PAP dimers, less favorable conformers lacking hydrogen bonding are populated at lower temperatures compared to PUP dimers. However, it should be mentioned that the hydrogen bond in $\mathbf{3 c}$ does not collapse even at $140{ }^{\circ} \mathrm{C}$, while $20 \mathrm{~b}$ starts thermal decomposition at this temperature.

The N-H stretching vibration of the IR spectra was indicative of hydrogen bonding in the solid state. Compound 9c showed two absorptions at 3472 and $3350 \mathrm{~cm}^{-1}$, the former of which can be attributed to the free amino group, and the latter to the hydrogen-bonded $\mathrm{N}-\mathrm{H}$ group arising from a restricted rotation of phthalimide- $\mathrm{NH}_{2}$ bond in the solid state. In the lower wavenumber region the $\mathrm{N}-\mathrm{H}$ stretching vibrations appear in the order: $\mathbf{4 c}\left(3317 \mathrm{~cm}^{-1}\right)>\mathbf{3 c}$ $\left(3293 \mathrm{~cm}^{-1}\right)$. This reflects the fact that the 6-aminophthalimide substituent is a weaker electron acceptor than (b)

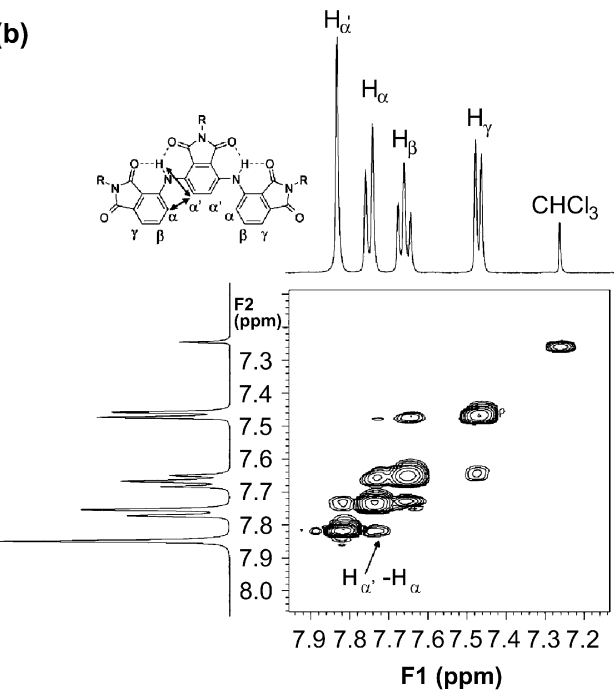

Figure 3. (a) Expanded ${ }^{1} \mathrm{H}$ NMR spectra of PAP dimer 3c, trimer 4c, 3-acetylaminophthalimide 8c, 3-aminophthalimide 9c, and PUP dimer 20b in CDCl 3 . Arrows mark the signal of NH proton. (b) $2 \mathrm{D}$ NOESY spectrum of trimer $\mathbf{4 c}$ in $\mathrm{CDCl}_{3}(298 \mathrm{~K}$, mixing time $0.1 \mathrm{~s})$. 


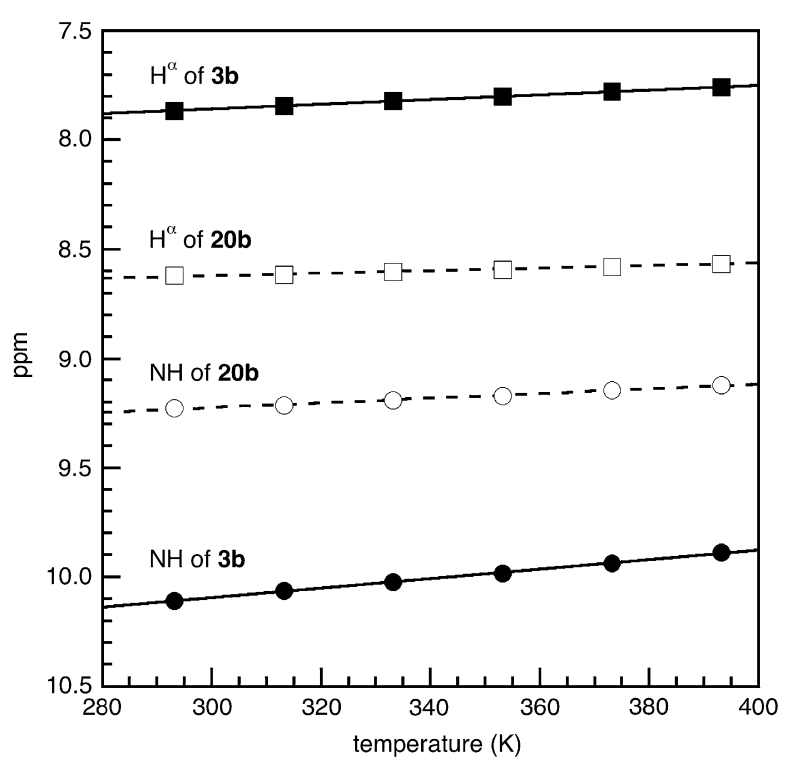

Figure 4. Temperature dependence of ${ }^{1} \mathrm{H}$ NMR signals of $\mathrm{NH}$ and $\mathrm{H}^{\alpha}$ protons of $\mathbf{3 b}$ and 20b in 1,1,2,2-tetrachloroethane- $d_{2}$.

a phthalimide substituent. Hence, the $\mathrm{N}-\mathrm{H}$ function in the dimer is more acidic than the $\mathrm{N}-\mathrm{H}$ functions in the trimer resulting in a stronger hydrogen bonding of the former.

The structures of $\mathbf{3 a}, \mathbf{3 b}$, and $\mathbf{2 0 a}$ in the solid state were unambiguously determined by single-crystal X-ray diffraction analysis. Their molecular structures are illustrated in Figure 5. Table 3 lists the selected bond distances and dihedral angles. As expected from the spectroscopic studies described above, an intramolecular hydrogen bonding between the NH proton and the imide oxygen is present in each compound. The hydrogen bond distances of PAP dimers 3a,b are $0.15-0.35 \AA$ longer than that of PUP dimer 20a. The two phthalimide units ( $A$ and $B$ ) in $\mathbf{3 a}, \mathbf{b}$ are mutually tilted by $35-41^{\circ}$ to avoid a steric (and possibly electrostatic) repulsion between the aromatic ortho protons. It seems that the tilt angle is influenced by substitution on the phenyl rings, when one compares $\mathbf{3 a}$ and $\mathbf{3 b}$. Unlike $\mathbf{3}$, 20a features a nearly planar structure, in which the urea oxygen and the phthalimide $\mathrm{H}^{\alpha}$ protons are also located in the range of hydrogen bond distances. This fact may rationalize the downfield shift of the signal of $\mathrm{H}^{\alpha}$ in the ${ }^{1} \mathrm{H}$ NMR spectrum of $20 \mathbf{b}$ (Fig. 3).

\subsection{Computational investigation and comparison with X-ray structures}

Density functional theory (DFT) was used to study the conformational preference of PUP dimers and PAP dimers in more detail. DFT, as introduced by Kohn and Sham, ${ }^{42}$ is a computationally very effective method that includes electron correlation effects. DFT has been used to accurately describe hydrogen bonding in DNA base pairs, ${ }^{43}$ quadruple hydrogen-bonded dimers, ${ }^{44}$ and to study the effect of hydrogen bonding on the conformational preference of pyrimidine-4,6-dicarboxamide based foldamers. ${ }^{45}$

Calculations were performed on small model molecules, PUP dimer 22 and PAP dimer 23 (Fig. 6) in which the phenyl group was replaced by a methyl group. Geometries were optimized using the hybrid $\mathrm{B} 3 \mathrm{LY} \mathrm{P}^{46}$ density functional using a 6-311G triple split valence basis sets ${ }^{47}$ and polarization functions $^{48}$ (B3LYP/6-311G(d,p)). The final geometries were re-optimized using additional diffuse functions ${ }^{49}$ (B3LYP/6-311+G(d,p)) on C, N, and O. The latter basis
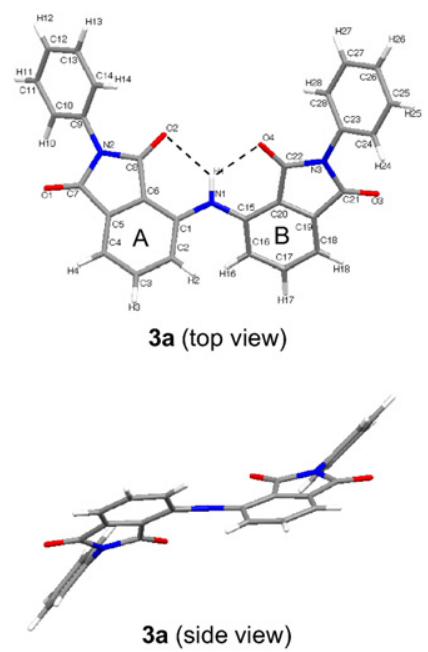

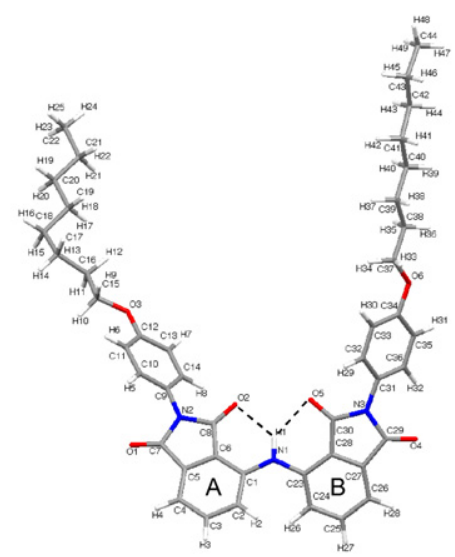

3b (top view)

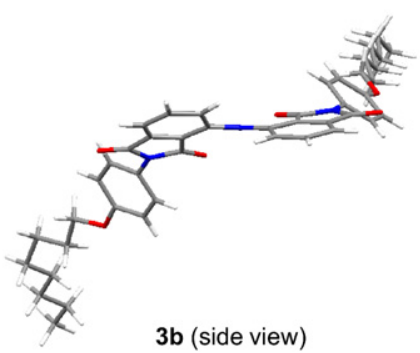

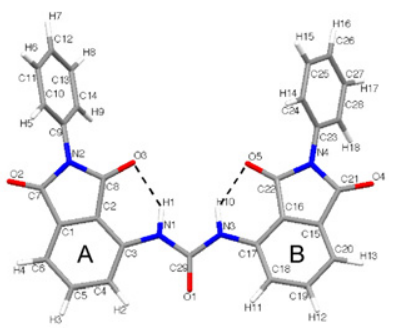

20a (top view)

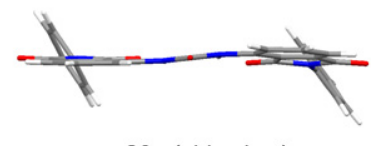

20a (side view)

Figure 5. Single-crystal X-ray structures of 3a, 3b, and 20a. Solvent molecule THF is omitted for 3a. 
Table 3. Selected bond distances $(\AA)$ and angles $\left(^{\circ}\right)$ and dihedral angles $\left(^{\circ}\right)$ for 3a, 3b, and 20a

\begin{tabular}{|c|c|c|c|c|c|}
\hline \multicolumn{2}{|l|}{$3 \mathbf{a}$} & \multicolumn{2}{|l|}{$\mathbf{3 b}$} & \multicolumn{2}{|l|}{$20 \mathbf{a}$} \\
\hline $\mathrm{N}(1)-\mathrm{C}(1)$ & $1.3898(17)$ & $\mathrm{N}(1)-\mathrm{C}(1)$ & $1.379(2)$ & $\mathrm{N}(1)-\mathrm{C}(3)$ & $1.391(3)$ \\
\hline $\mathrm{N}(1)-\mathrm{C}(15)$ & 1.3841(18) & $\mathrm{N}(1)-\mathrm{C}(23)$ & $1.386(2)$ & $\mathrm{N}(3)-\mathrm{C}(17)$ & $1.390(3)$ \\
\hline $\mathrm{N}(1)-\mathrm{H}(1)$ & $0.877(18)$ & $\mathrm{N}(1)-\mathrm{H}(1)$ & $0.870(18)$ & $\mathrm{N}(1)-\mathrm{H}(1)$ & $0.95(3)$ \\
\hline $\mathrm{H}(1) \cdots \mathrm{O}(2)$ & $2.404(18)$ & $\mathrm{H}(1) \cdots \mathrm{O}(2)$ & $2.362(18)$ & $\mathrm{N}(3)-\mathrm{H}(10)$ & $0.95(3)$ \\
\hline $\mathrm{H}(1) \cdots \mathrm{O}(4)$ & $2.374(17)$ & $\mathrm{H}(1) \cdots \mathrm{O}(5)$ & $2.211(18)$ & $\mathrm{H}(1) \cdots \mathrm{O}(3)$ & $2.03(3)$ \\
\hline & & & & $\mathrm{H}(10) \cdots \mathrm{O}(5)$ & $2.06(3)$ \\
\hline $\mathrm{N}(1)-\mathrm{H}(1) \cdots \mathrm{O}(2)$ & $126.1(14)$ & $\mathrm{N}(1)-\mathrm{H}(1) \cdots \mathrm{O}(2)$ & $127.2(16)$ & $\mathrm{N}(1)-\mathrm{H}(1) \cdots \mathrm{O}(3)$ & $144(2)$ \\
\hline $\mathrm{N}(1)-\mathrm{H}(1) \cdots \mathrm{O}(4)$ & $124.6(14)$ & $\mathrm{N}(1)-\mathrm{H}(1) \cdots \mathrm{O}(5)$ & 136.1(16) & $\mathrm{N}(3)-\mathrm{H}(10) \cdots \mathrm{O}(5)$ & $141(2)$ \\
\hline $\mathrm{C}(16)-\mathrm{C}(15)-\mathrm{N}(1)-\mathrm{C}(1)$ & $22.5(2)$ & $\mathrm{C}(2)-\mathrm{C}(1)-(\mathrm{N} 1)-\mathrm{C}(23)$ & $25.9(3)$ & $\mathrm{H}(10)-\mathrm{N}(3)-\mathrm{C}(17)-\mathrm{C}(18)$ & $178.3(17)$ \\
\hline $\mathrm{C}(2)-\mathrm{C}(1)-\mathrm{N}(1)-\mathrm{C}(15)$ & $26.4(2)$ & $\mathrm{C}(24)-\mathrm{C}(23)-\mathrm{N}(1)-\mathrm{C}(1)$ & $18.2(3)$ & $\mathrm{H}(2)-\mathrm{O}(1)-\mathrm{C}(29)-\mathrm{H}(11)$ & $173.7(9)$ \\
\hline
\end{tabular}

Estimated standard deviation in parentheses.

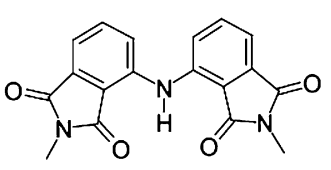

(syn-syn, $0 \mathrm{kcal} / \mathrm{mol})$

22a

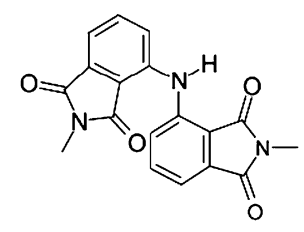

(syn-anti, $+3 \mathrm{kcal} / \mathrm{mol}$ )

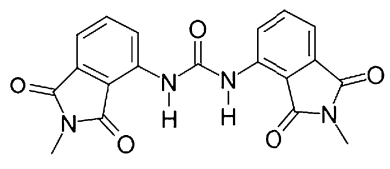

(transoid-transoid , $0 \mathrm{kcal} / \mathrm{mol}$ )

23a

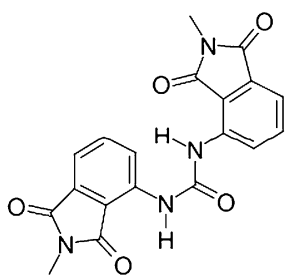

(cisoid-transoid, $+5 \mathrm{kcal} / \mathrm{mol}$ )

$23 b$

Figure 6. Relative energies of PAP dimer and PUP dimer conformers.

set has sufficient diffuseness and angular flexibility to provide a reasonable description of strong intramolecular secondary interactions.

Results from the gas-phase calculations suggest that the synsyn conformation of PAP dimer 22a is energetically favored over the syn-anti conformation $\mathbf{2 2 b}$ by approximately $3 \mathrm{kcal} / \mathrm{mol}$. Compared to the crystal structure, the bond lengths of the DFT optimized structure of 22a are similar (deviations between 0.001 and $0.01 \AA$ ) except for the $\mathrm{N}-\mathrm{H}$ bond length, which is overestimated by DFT (Table S2). The length of the intramolecular hydrogen bond, represented by $\mathrm{H}(1) \cdots \mathrm{O}(2)$ in 22a is $2.31 \AA$, which is shorter than in the crystal structure $(2.39 \AA)$. Previous studies ${ }^{50}$ on neutral intermolecular hydrogen-bonded complexes have shown that B3LYP tends to underestimate hydrogen bond strengths and provides incorrect $\mathrm{H}$-bond distances compared to MP2 as a result of an incorrect description of dispersion energy ${ }^{51}$ by current DFT methods. As expected, the error in the H-bond length is larger for the geometry optimized without additional diffuse functions $(2.29 \AA)$. It must be noted, however, that the uncertainty regarding the location of the $\mathrm{H}$ atom in $\mathrm{N}-\mathrm{H} \cdots \mathrm{O}$ hydrogen bonds, obtained through $\mathrm{X}$-ray diffraction experiments has been documented ${ }^{52}$ and therefore direct comparison of the hydrogen bond lengths in the X-ray structure and the B3LYP optimized geometry is troublesome. On the other hand, DFT correctly predicts the non-planarity of the backbone of 22a and good agreement is found between the dihedral angles when compared to the angles in crystal structure 3a (Fig. 7). For example, the (pseudo)torsional angle $\mathrm{C}(16)-\mathrm{C}(25)-\mathrm{C}(1)-\mathrm{C}(2)$ defining the angle between the two phthalimide plains are $40.78^{\circ}$ in $\mathbf{3 a}$ and $38.58^{\circ}$ in 22a, reflecting the excellent agreement between theory and experiment. The distances between the two phthalimide units, represented by the distance between $\mathrm{H}(2)$ and $\mathrm{H}(16)$ are almost similar in crystal structure 3a $(2.22 \AA)$ and the calculated geometry $(2.20 \AA)$. Comparison of other important dihedral angles shows that DFT accurately predicts both the $\mathrm{C}(2)-\mathrm{C}(1)$ $\mathrm{N}(1)-\mathrm{C}(15)$ and $\mathrm{C}(16)-\mathrm{C}(15)-\mathrm{N}(1)-\mathrm{C}(1)$ dihedral angles (Table S3).

The transoid-transoid conformation of PUP dimer as represented by 23a is $5 \mathrm{kcal} / \mathrm{mol}$ more stable than the corresponding transoid-cisoid conformer. This value is somewhat larger compared to the value reported by Gong and coworkers $^{7 \mathrm{f}}$ for ortho ester substituted aromatic ureas using the same B3LYP functional and basis set. This difference is most probably the result of the enforced planarity of the imide carbonyl resulting in a maximum strength of the hydrogen bonds. However, it must be noted that depending on the method of calculation, ${ }^{53}$ large differences between the relative stabilities of the cisoid and transoid conformers of phenylurea have been found. Without considering the N$\mathrm{H}$ bond lengths, the absolute deviations found for bond lengths between 23a and 20a are small (between 0.001 and $0.01 \AA$ ). In contrast to PAP dimer $\mathbf{3 a}$, the deviations between the dihedral angles of 23a and 20a are considerable. For example, DFT predicts the $\mathrm{C}(29)-\mathrm{N}(1)-\mathrm{C}(3)-\mathrm{C}(4)$ dihedral angle to be $0^{\circ}$ (resulting in a planar conformation) while it is $-8.8^{\circ} \pm 3^{\circ}$ in the crystal structure (Table S5). Any attempts to minimize a non-planar transoid-transoid starting geometry resulted in a planar optimized geometry indicating that the planar geometry is indeed the global minimum using the current computational method. The discussed divergence may rely on two factors. First, it can be due to the larger steric hindrance of the phenyl groups in $\mathbf{2 0 a}$ as compared to the methyl groups in 23a thereby forcing the phthalimide units out of plane. Second, Bickelhaupt and co-workers ${ }^{54}$ showed that the molecular environment in the unit cell may cause 


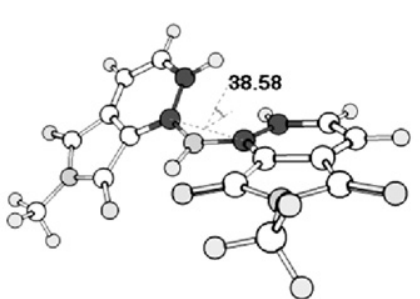

$22 a$

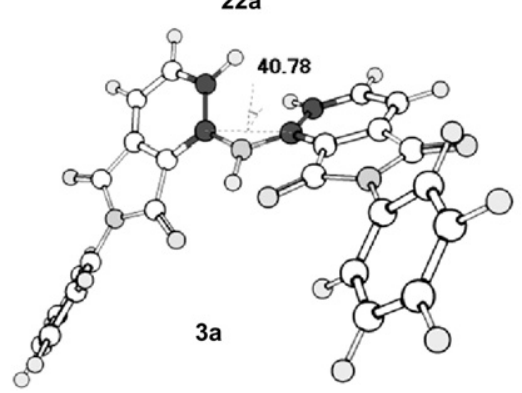

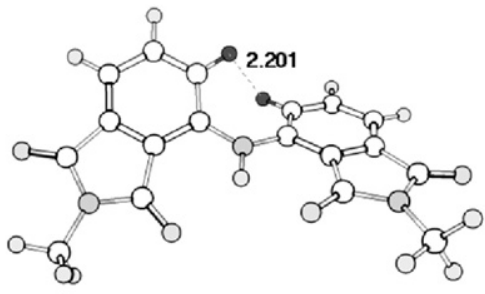

$22 a$

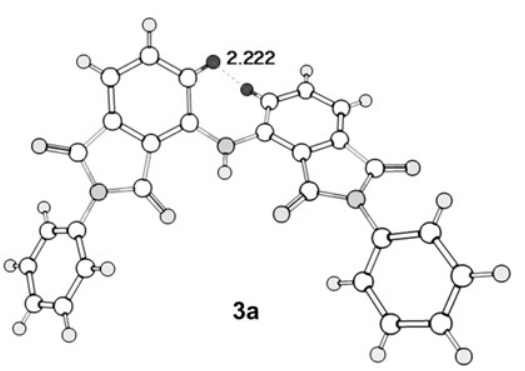

Figure 7. Comparison of $\mathrm{C}(16)-\mathrm{C}(25)-\mathrm{C}(1)-\mathrm{C}(2)$ dihedral angle and distances between $\mathrm{H}(2)$ and $\mathrm{H}(16)$ in crystal structure 3a and B3LYP optimized structure 22a.

significant deviation between theoretical results and the experimentally determined X-ray structure.

Although a direct comparison is difficult to make due to the absence of solvent effects in the gas-phase calculations, it is striking that the same order of stability between the PUP and PAP dimers was also observed in the analysis of the temperature dependence of ${ }^{1} \mathrm{H}$ NMR signals of $\mathrm{NH}$ and $\mathrm{H}^{\alpha}$ protons of $\mathbf{3 b}$ and $\mathbf{2 0 b}$ in 1,1,2,2-tetrachloroethane- $d_{2}$.

\section{Conclusion}

The synthesis of PAP dimers 3 and trimers $\mathbf{4}$ has been successfully performed by Buchwald-Hartwig amination. The use of chlorophthalimide as a coupling partner, $\mathrm{Pd}(\mathrm{OAc})_{2} /$ XPhos as a catalyst system, and $\mathrm{K}_{3} \mathrm{PO}_{4}$ as a base is of particular importance to reach a selective and quantitative conversion. The structural analysis of $\mathbf{3}$ and $\mathbf{4}$ in solution as well as in the solid state points to bifurcated hydrogen bonding between the amine protons and the adjacent imide oxygens, which is responsible for locking the conformation of the phthalimide backbone. The DFT calculations are indicative that the syn-syn conformation of diphthalimidylamine unit is energetically more stable than the syn-anti conformer. Taking all these data as well as our previous findings on PUP foldamers into account, it is strongly expected that the aminophthalimide backbone is capable of adopting a folded conformation with a smaller number of repeating units as compared to PUP. Furthermore, both temperature dependent ${ }^{1} \mathrm{H}$ NMR and DFT studies suggest that the conformational lock in PAP dimers is significantly loosened compared to PUP dimers. It is expected that such a design will lead to foldamers with a significantly more dynamical folding character as compared to PUP oligomers due to loosening of the conformational lock.

Also noteworthy is that the aminophthalimide compound is thermally and chemically more stable than the corresponding ureidophthalimide, which would allow in-depth study of physical and chemical properties of the resulting PAP foldamers. Synthesis of discrete oligomers and folding behavior of PAP is now under investigation.

\section{Experimental section}

\subsection{General}

All chemicals were purchased from Aldrich or Acros and were used as received unless stated otherwise. Dioxane was freshly distilled from $4 \AA$ molecular sieves, toluene was freshly distilled from $\mathrm{Na}$; $\mathrm{CDCl}_{3}$ was dried over $4 \AA$ molecular sieves and THF was distilled from $4 \AA$ molecular sieves.

The coupling reactions were carried out under dry argon. All reactions were followed by thin-layer chromatography (precoated $0.25 \mathrm{~mm}$ silica gel plates from Merck), and silica gel column chromatography was carried out with silica gel 60 (mesh 70-230). ${ }^{1} \mathrm{H}$ and ${ }^{13} \mathrm{C}$ NMR spectra were recorded on a $400 \mathrm{MHz}$ NMR (Varian Mercury, $400 \mathrm{MHz}$ for ${ }^{1} \mathrm{H}$ NMR and $100 \mathrm{MHz}$ for ${ }^{13} \mathrm{C}$ NMR), a $300 \mathrm{MHz}$ NMR (Varian Gemini, $300 \mathrm{MHz}$ for ${ }^{1} \mathrm{H}$ NMR and $75 \mathrm{MHz}$ for ${ }^{13} \mathrm{C}$ $\mathrm{NMR}$ ), or $500 \mathrm{MHz}$ NMR (Varian Unity Inova, $500 \mathrm{MHz}$ for ${ }^{1} \mathrm{H}$ NMR and $125 \mathrm{MHz}$ for ${ }^{13} \mathrm{C}$ NMR). Proton chemical shifts are reported in parts per million downfield from tetramethylsilane (TMS) and the coupling constant, $J$, is reported in hertz $(\mathrm{Hz})$. The following splitting patterns are designated as s, singlet; d, doublet; t, triplet; q, quartet; br, broad; m, multiplet. Carbon chemical shifts are reported downfield from TMS using the resonance of the deuterated solvent as the internal standard. Temperature calibration for VT NMR was achieved by observing the temperature dependent chemical-shift separation between the $\mathrm{OH}$ resonances and $\mathrm{CH}_{n}$ resonances in ethylene glycol. Matrix assisted laser desorption/ionization mass-time of flight (MALDI-TOF) was obtained using a PerSeptive Biosystems Voyager-DE PRO spectrometer. Infrared (IR) spectra were recorded on a Perkin-Elmer Spectrum One FTIR spectrometer with 
a Universal ATR sampling accessory. Elemental analysis was performed on a Perkin-Elmer 2400 series II CHNS/O Analyzer. Melting points were determined on a Büchi Melting Point B-540 apparatus.

4.1.1. 3-Acetylamino- $N$-(3,4,5-tridodecyloxyphenyl)phthalimide (8c). A solution of 3-acetylaminophthalic anhydride (6) (0.541 g, $2.64 \mathrm{mmol})$ and 3,4,5-tridodecyloxyaniline (7c) $(2.05 \mathrm{~g}, 3.17 \mathrm{mmol})$ in acetic acid $(26 \mathrm{~mL})$ was stirred at $100{ }^{\circ} \mathrm{C}$ for $12 \mathrm{~h}$. The resulting black suspension was cooled to room temperature and then evaporated. The residue was purified by flash column chromatography on silica gel, eluted with $\mathrm{CH}_{2} \mathrm{Cl}_{2}$ to give $\mathbf{8 c}$ as a pale brown solid (2.15 g, 98\% yield). ${ }^{1} \mathrm{H} \mathrm{NMR}\left(\mathrm{CDCl}_{3}\right): \delta 9.64(\mathrm{~s}, 1 \mathrm{H}, \mathrm{NH})$, $8.84\left(\mathrm{~d}, J=8.4 \mathrm{~Hz}, 1 \mathrm{H}, \mathrm{H}^{4}\right.$ of $\left.\mathrm{C}_{6} \mathrm{H}_{3}\right), 7.74(\mathrm{dd}, J=8.4$, $7.3 \mathrm{~Hz}, 1 \mathrm{H}, \mathrm{H}^{5}$ of $\left.\mathrm{C}_{6} \mathrm{H}_{3}\right), 7.60\left(\mathrm{~d}, J=7.3 \mathrm{~Hz}, 1 \mathrm{H}, \mathrm{H}^{6}\right.$ of $\left.\mathrm{C}_{6} \mathrm{H}_{3}\right), 6.57\left(\mathrm{~s}, 2 \mathrm{H}, \mathrm{H}^{2,6}\right.$ of $\left.\mathrm{C}_{6} \mathrm{H}_{2}\right), 4.01-3.95(\mathrm{~m}, 6 \mathrm{H}$, $\left.\mathrm{OCH}_{2}\right), 2.27\left(\mathrm{~s}, 3 \mathrm{H}, \mathrm{COCH}_{3}\right), 1.84-1.73\left(\mathrm{~m}, 6 \mathrm{H}, \mathrm{OCH}_{2} \mathrm{CH}_{2}\right)$, $1.52-1.21\left(\mathrm{~m}, 54 \mathrm{H}, \mathrm{CH}_{2}\right), 0.93-0.86\left(\mathrm{~m}, 9 \mathrm{H}, \mathrm{CH}_{3}\right) .{ }^{13} \mathrm{C}\left\{{ }^{1} \mathrm{H}\right\}$ NMR $\left(\mathrm{CDCl}_{3}\right): \delta 169.4(\mathrm{C}=\mathrm{O}), 169.2(\mathrm{NHCO}), 166.8$ $(\mathrm{C}=\mathrm{O}), 153.3\left(\mathrm{C}^{3,5}\right.$ of $\left.\mathrm{C}_{6} \mathrm{H}_{2}\right), 138.1\left(\mathrm{C}^{3}\right.$ of $\left.\mathrm{C}_{6} \mathrm{H}_{3}\right), 137.7$ $\left(\mathrm{C}^{4}\right.$ of $\left.\mathrm{C}_{6} \mathrm{H}_{2}\right), 136.3\left(\mathrm{C}^{5}\right.$ of $\left.\mathrm{C}_{6} \mathrm{H}_{3}\right), 131.1\left(\mathrm{C}^{1}\right.$ of $\left.\mathrm{C}_{6} \mathrm{H}_{3}\right)$, $125.9\left(\mathrm{C}^{1}\right.$ of $\left.\mathrm{C}_{6} \mathrm{H}_{2}\right), 125.0\left(\mathrm{C}^{4}\right.$ of $\left.\mathrm{C}_{6} \mathrm{H}_{3}\right), 118.3\left(\mathrm{C}^{6}\right.$ of $\left.\mathrm{C}_{6} \mathrm{H}_{3}\right), 115.2\left(\mathrm{C}^{2}\right.$ of $\left.\mathrm{C}_{6} \mathrm{H}_{3}\right), 105.3\left(\mathrm{C}^{2,6}\right.$ of $\left.\mathrm{C}_{6} \mathrm{H}_{2}\right), 73.5$ (4$\left.\mathrm{OCH}_{2}\right), 69.2\left(3,5-\mathrm{OCH}_{2}\right), 32.0,31.9,30.3,29.8,29.7,29.6$, 29.4, 29.3, 26.1, 26.0, 25.0, $22.6\left(\right.$ each $\left.\mathrm{CH}_{2}\right), 14.1\left(\mathrm{CH}_{3}\right)$. IR (ATR): 3361, 2919, 2851, 1764, 1698, 1621, 1597, 1533, 1505, 1481, 1468, 1437, 1413, 1390, 1377, 1307, 1260, 1233, 1180, 1118, 1016, 903, 868, 798, 747, 720, $684 \mathrm{~cm}^{-1}$. Anal. Calcd for $\mathrm{C}_{52} \mathrm{H}_{84} \mathrm{~N}_{2} \mathrm{O}_{6}$ : C, 74.96; $\mathrm{H}$, 10.16; N, 3.36. Found: C, 74.99; H, 10.20; N, 3.29.

4.1.2. 3-Amino- $N$-(3,4,5-tridodecyloxyphenyl)phthalimide (9c). To a solution of $8 \mathbf{c}(2.10 \mathrm{~g}, 2.52 \mathrm{mmol})$ in 1,4-dioxane $(80 \mathrm{~mL})$ was added $37 \%$ aq $\mathrm{HCl}(7.1 \mathrm{~mL})$, and the mixture was stirred at $100{ }^{\circ} \mathrm{C}$ for $4 \mathrm{~h}$. The mixture was cooled to room temperature and then neutralized with $25 \%$ aq $\mathrm{NH}_{3}$. The mixture was extracted with $\mathrm{CH}_{2} \mathrm{Cl}_{2}$, washed with brine, and dried over $\mathrm{MgSO}_{4}$. After removal of the drying agent the filtrate was evaporated to give a yellow solid, which was purified by flash column chromatography on silica gel eluted with $\mathrm{CH}_{2} \mathrm{Cl}_{2}$ /hexane $(6 / 1)$ to give 9c as yellow crystals (1.61 g, 81\% yield). ${ }^{1} \mathrm{H} \mathrm{NMR}\left(\mathrm{CDCl}_{3}\right): \delta 7.47$ (dd, $J=8.4$, $7.3 \mathrm{~Hz}, 1 \mathrm{H}, \mathrm{H}^{5}$ of $\left.\mathrm{C}_{6} \mathrm{H}_{3}\right), 7.23\left(\mathrm{~d}, J=7.3 \mathrm{~Hz}, 1 \mathrm{H}, \mathrm{H}^{6}\right.$ of $\left.\mathrm{C}_{6} \mathrm{H}_{3}\right), 6.90\left(\mathrm{~d}, J=8.4 \mathrm{~Hz}, 1 \mathrm{H}, \mathrm{H}^{4}\right.$ of $\left.\mathrm{C}_{6} \mathrm{H}_{3}\right), 6.59(\mathrm{~s}, 2 \mathrm{H}$, $\mathrm{C}_{6} \mathrm{H}_{2}$ ), 5.30 (br s, 2H, $\mathrm{NH}_{2}$ ), 3.99-3.95 (m, 6H, $\mathrm{OCH}_{2}$ ), 1.83-1.72 (m, 6H, $\left.\mathrm{OCH}_{2} \mathrm{CH}_{2}\right), 1.53-1.20\left(\mathrm{~m}, 54 \mathrm{H}, \mathrm{CH}_{2}\right)$, 0.90-0.86 (m, 9H, CH 3$).{ }^{13} \mathrm{C}\left\{{ }^{1} \mathrm{H}\right\}$ NMR $\left(\mathrm{CDCl}_{3}\right): \delta 169.3$, 167.7 (each $\mathrm{C}=\mathrm{O}), 153.2\left(\mathrm{C}^{3,5}\right.$ of $\left.\mathrm{C}_{6} \mathrm{H}_{2}\right), 145.6\left(\mathrm{C}^{3}\right.$ of $\left.\mathrm{C}_{6} \mathrm{H}_{3}\right), 137.8\left(\mathrm{C}^{1}\right.$ of $\left.\mathrm{C}_{6} \mathrm{H}_{2}\right), 135.5\left(\mathrm{C}^{5}\right.$ of $\left.\mathrm{C}_{6} \mathrm{H}_{3}\right), 132.4\left(\mathrm{C}^{1}\right.$ of $\left.\mathrm{C}_{6} \mathrm{H}_{3}\right), 126.7\left(\mathrm{C}^{4}\right.$ of $\left.\mathrm{C}_{6} \mathrm{H}_{2}\right), 121.2\left(\mathrm{C}^{4}\right.$ of $\left.\mathrm{C}_{6} \mathrm{H}_{3}\right), 113.1$ $\left(\mathrm{C}^{6}\right.$ of $\left.\mathrm{C}_{6} \mathrm{H}_{3}\right), 110.9\left(\mathrm{C}^{2}\right.$ of $\left.\mathrm{C}_{6} \mathrm{H}_{3}\right), 105.4\left(\mathrm{C}^{2,6}\right.$ of $\left.\mathrm{C}_{6} \mathrm{H}_{2}\right)$, $73.5\left(4-\mathrm{OCH}_{2}\right), 69.1\left(3,5-\mathrm{OCH}_{2}\right), 32.0,31.9,30.4,29.8$, 29.8, 29.7, 29.7, 29.7, 29.4, 29.4, 29.3, 26.1, 26.1, 22.7 (each $\left.\mathrm{CH}_{2}\right), 14.1\left(\mathrm{CH}_{3}\right)$. IR (ATR): 3472, 3340, 2956, 2923, 2852, 1743, 1702, 1639, 1596, 1508, 1482, 1468, 1439, 1416, 1389, 1310, 1237, 1191, 1132, 1120, 1098, 1026, 984, 939, 878, 820, 773, 741, 723, 704, $679 \mathrm{~cm}^{-1}$. Anal. Calcd for $\mathrm{C}_{50} \mathrm{H}_{82} \mathrm{~N}_{2} \mathrm{O}_{5}: \mathrm{C}, 75.90 ; \mathrm{H}, 10.45 ; \mathrm{N}, 3.54$. Found: C, 75.93; H, 10.50; N, 3.33.

4.1.3. 3-Chloro- $N$-(3,4,5-tridodecyloxyphenyl)phthalimide (10c). A mixture of 3-chlorophthalic anhydride
(71.1 $\mathrm{mg}, 0.389 \mathrm{mmol})$ and $7 \mathrm{c}(304 \mathrm{mg}, 0.471 \mathrm{mmol})$ in acetic acid $(1.5 \mathrm{~mL})$ was refluxed at $135^{\circ} \mathrm{C}$ for $1 \mathrm{~h}$ with stirring. The mixture was cooled to room temperature, and then the resulting gray suspension was extracted with $\mathrm{CHCl}_{3}$ and water. The combined organic layers were dried over $\mathrm{MgSO}_{4}$. The drying agent was filtered off, and the filtrate was evaporated to give a pale brown solid, which was purified by flash column chromatography on silica gel eluted with $\mathrm{CH}_{2} \mathrm{Cl}_{2}$ / heptane $(1 / 1)$ to give 10c as a white solid $(0.206 \mathrm{~g}, 65 \%$ yield). ${ }^{1} \mathrm{H}$ NMR $\left(\mathrm{CDCl}_{3}\right): \delta 7.88-7.84\left(\mathrm{~m}, 1 \mathrm{H}, \mathrm{H}_{6}\right.$ of $\left.\mathrm{C}_{6} \mathrm{H}_{3}\right), 7.73-7.68\left(\mathrm{~m}, 2 \mathrm{H}, \mathrm{H}^{4,5}\right.$ of $\left.\mathrm{C}_{6} \mathrm{H}_{3}\right), 6.60\left(\mathrm{~s}, 2 \mathrm{H}, \mathrm{C}_{6} \mathrm{H}_{2}\right)$, $3.99\left(\mathrm{t}, J=6.6 \mathrm{~Hz}, 2 \mathrm{H}, 4-\mathrm{OCH}_{2}\right), 3.96(\mathrm{t}, J=6.6 \mathrm{~Hz}, 4 \mathrm{H}, 3,5-$ $\left.\mathrm{OCH}_{2}\right), 1.83-1.72\left(\mathrm{~m}, 6 \mathrm{H}, \mathrm{OCH}_{2} \mathrm{CH}_{2}\right), 1.52-1.42,1.38-1.20$ (each m, 54H, $\left.\mathrm{CH}_{2}\right), 0.90-0.86\left(\mathrm{~m}, 9 \mathrm{H}, \mathrm{CH}_{3}\right) .{ }^{13} \mathrm{C}\left\{{ }^{1} \mathrm{H}\right\} \mathrm{NMR}$ $\left(\mathrm{CDCl}_{3}\right): \delta$ 166.0, $165.0($ each $\mathrm{C}=\mathrm{O}), 153.3\left(\mathrm{C}^{3,5}\right.$ of $\left.\mathrm{C}_{6} \mathrm{H}_{2}\right)$, $138.1\left(\mathrm{C}^{1}\right.$ of $\left.\mathrm{C}_{6} \mathrm{H}_{2}\right), 136.1,135.2$ (each $\mathrm{C}^{4}$ or 5 of $\left._{6} \mathrm{H}_{3}\right), 133.9$ $\left(\mathrm{C}^{1}\right.$ of $\left.\mathrm{C}_{6} \mathrm{H}_{3}\right), 131.9\left(\mathrm{C}^{2}\right.$ of $\left.\mathrm{C}_{6} \mathrm{H}_{3}\right), 127.4\left(\mathrm{C}^{3}\right.$ of $\left.\mathrm{C}_{6} \mathrm{H}_{3}\right), 126.2$ $\left(\mathrm{C}^{4}\right.$ of $\left.\mathrm{C}_{6} \mathrm{H}_{2}\right), 122.2\left(\mathrm{C}^{6}\right.$ of $\left.\mathrm{C}_{6} \mathrm{H}_{3}\right), 105.4\left(\mathrm{C}^{2,6}\right.$ of $\left.\mathrm{C}_{6} \mathrm{H}_{2}\right), 73.5$ $\left(4-\mathrm{OCH}_{2}\right), 69.2\left(3,5-\mathrm{OCH}_{2}\right), 31.9,30.4,29.8,29.7,29.7$, 29.6, 29.4, 29.4, 29.3, 26.1, 26.1, $22.7\left(\right.$ each $\left.\mathrm{CH}_{2}\right), 14.1$ $\left(\mathrm{CH}_{3}\right)$. IR (ATR): 2920, 2849, 1769, 1714, 1601, 1506, 1465, 1437, 1396, 1356, 1308, 1241, 1116, 891, 772, $741 \mathrm{~cm}^{-1}$. Anal. Calcd for $\mathrm{C}_{22} \mathrm{H}_{24} \mathrm{ClNO}_{3}: \mathrm{C}, 68.48 ; \mathrm{H}$, 6.27; N, 3.63. Found: C, 68.59; H, 6.27; N, 3.69.

4.1.4. 3,6-Dichloro- $N$-(3,4,5-tridodecyloxyphenyl)phthalimide (12c). A mixture of 3,6-dichlorophthalic anhydride $(1.40 \mathrm{~g}, 6.45 \mathrm{mmol})$ and $7 \mathrm{c}(5.01 \mathrm{~g}, 7.75 \mathrm{mmol})$ in acetic acid $(26 \mathrm{~mL})$ was refluxed at $135^{\circ} \mathrm{C}$ for $1 \mathrm{~h}$ with stirring. The mixture was cooled to room temperature, and then the resulting gray suspension was extracted with $\mathrm{CHCl}_{3}$ and water. The combined organic layers were dried over $\mathrm{MgSO}_{4}$. The drying agent was filtered off, and the filtrate was evaporated to give a brown solid, which was purified by flash column chromatography on silica gel, eluted with $\mathrm{CHCl}_{3} /$ hexane $(1 / 1)$ to give $\mathbf{1 2 c}$ as a pale orange solid (3.54 g, 65\%). ${ }^{1} \mathrm{H}$ NMR $\left(\mathrm{CDCl}_{3}\right): \delta 7.63\left(\mathrm{~s}, 2 \mathrm{H}, \mathrm{C}_{6} \mathrm{H}_{2} \mathrm{Cl}_{2}\right)$, $6.60\left(\mathrm{~s}, 2 \mathrm{H}, \mathrm{C}_{6} \mathrm{H}_{2}\left(\mathrm{OC}_{12} \mathrm{H}_{25}\right)_{3}\right), 3.99(\mathrm{t}, J=6.6 \mathrm{~Hz}, 2 \mathrm{H}, 4-$ $\left.\mathrm{OCH}_{2}\right), 3.96\left(\mathrm{t}, J=6.6 \mathrm{~Hz}, 4 \mathrm{H}, 3,5-\mathrm{OCH}_{2}\right), 1.83-1.73(\mathrm{~m}$, $\left.6 \mathrm{H}, \mathrm{OCH}_{2} \mathrm{CH}_{2}\right), 1.52-1.20\left(\mathrm{~m}, 54 \mathrm{H}, \mathrm{CH}_{2}\right), 0.92-0.85(\mathrm{~m}$, $\left.9 \mathrm{H}, \mathrm{CH}_{3}\right) .{ }^{13} \mathrm{C}\left\{{ }^{1} \mathrm{H}\right\} \mathrm{NMR}\left(\mathrm{CDCl}_{3}\right): \delta 163.7(\mathrm{C}=\mathrm{O}), 153.3$ $\left(\mathrm{C}^{3,5}\right.$ of $\left.\mathrm{C}_{6} \mathrm{H}_{2}(\mathrm{OR})_{3}\right), 138.2\left(\mathrm{C}^{1}\right.$ of $\left.\mathrm{C}_{6} \mathrm{H}_{2}(\mathrm{OR})_{3}\right), 136.9\left(\mathrm{C}^{4,5}\right.$ of $\left.\mathrm{C}_{6} \mathrm{H}_{2} \mathrm{Cl}_{2}\right), 130.4\left(\mathrm{C}^{3,6}\right.$ of $\left.\mathrm{C}_{6} \mathrm{H}_{2} \mathrm{Cl}_{2}\right), 128.8\left(\mathrm{C}^{1,2}\right.$ of $\left.\mathrm{C}_{6} \mathrm{H}_{2} \mathrm{Cl}_{2}\right), 125.9\left(\mathrm{C}^{4}\right.$ of $\left.\mathrm{C}_{6} \mathrm{H}_{2}(\mathrm{OR})_{3}\right), 105.3\left(\mathrm{C}^{2,6}\right.$ of $\left.\mathrm{C}_{6} \mathrm{H}_{2}(\mathrm{OR})_{3}\right), 73.5\left(4-\mathrm{OCH}_{2}\right), 69.2\left(3,5-\mathrm{OCH}_{2}\right), 31.9,30.4$, 29.8, 29.7, 29.7, 29.6, 29.4, 29.4, 29.3, 26.1, 26.1, 22.7 (each $\left.\mathrm{CH}_{2}\right), 14.1\left(\mathrm{CH}_{3}\right)$. IR (ATR): 2953, 2919, 2848, $1788,1766,1714,1601,1506,1466,1454,1438,1393$, 1353, 1306, 1240, 1180, 1130, 1115, 889, 830, 755, 723, 693, $668 \mathrm{~cm}^{-1}$. Anal. Calcd for $\mathrm{C}_{50} \mathrm{H}_{79} \mathrm{Cl}_{2} \mathrm{NO}_{5}$ : C, 71.06; H, 9.42; N, 1.66. Found: C, 70.82; H, 9.44; N, 1.63.

4.1.5. PAP dimer 3c. A Schlenk tube equipped with a stirbar was charged with 10c $(32.0 \mathrm{mg}, 39.5 \mu \mathrm{mol}), 9 \mathrm{c}(35.1 \mathrm{mg}$, $44.4 \mu \mathrm{mol}), \mathrm{Pd}(\mathrm{OAc})_{2}(0.44 \mathrm{mg}, 1.2 \mu \mathrm{mol})$, XPhos $(1.9 \mathrm{mg}$, $4.0 \mu \mathrm{mol})$, and $\mathrm{K}_{3} \mathrm{PO}_{4}(13.0 \mathrm{mg}, 61.2 \mu \mathrm{mol})$. The system was evacuated and backfilled with argon gas (this process was repeated three times), and then anhydrous toluene $(1.6 \mathrm{~mL})$ was added. The mixture was stirred at $100{ }^{\circ} \mathrm{C}$ for $24 \mathrm{~h}$. The resulting orange suspension was cooled to room temperature and then the solvent was removed by pumping to give an orange oil, which was purified by flash column chromatography on silica gel, eluted with $\mathrm{CH}_{2} \mathrm{Cl}_{2}$ /hexane 
(2/1) to give 3c as a yellow sticky solid (56 $\mathrm{mg}, 91 \%$ yield). ${ }^{1} \mathrm{H} \mathrm{NMR}\left(\mathrm{CDCl}_{3}\right): \delta 10.00(\mathrm{~s}, 1 \mathrm{H}, \mathrm{NH}), 7.83(\mathrm{~d}, J=8.4 \mathrm{~Hz}$, $2 \mathrm{H}, \mathrm{H}^{4}$ of $\mathrm{C}_{6} \mathrm{H}_{3}$ ), 7.69 (apparent $\mathrm{t}, J=7.9 \mathrm{~Hz}, 2 \mathrm{H}, \mathrm{H}^{5}$ of $\left.\mathrm{C}_{6} \mathrm{H}_{3}\right), 7.51\left(\mathrm{~d}, J=7.0 \mathrm{~Hz}, 2 \mathrm{H}, \mathrm{H}^{6}\right.$ of $\left.\mathrm{C}_{6} \mathrm{H}_{3}\right), 6.60(\mathrm{~s}, 4 \mathrm{H}$, $\left.\mathrm{C}_{6} \mathrm{H}_{2}\right)$, 3.99-3.94 (m, 12H, $\left.\mathrm{OCH}_{2}\right), 1.82-1.72(\mathrm{~m}, 12 \mathrm{H}$, $\mathrm{OCH}_{2} \mathrm{CH}_{2}$ ), 1.52-1.42, 1.38-1.19 (each m, $108 \mathrm{H}, \mathrm{CH}_{2}$ ), 0.90-0.86 (m, 18H, CH 3$).{ }^{13} \mathrm{C}\left\{{ }^{1} \mathrm{H}\right\}$ NMR $\left(\mathrm{CDCl}_{3}\right): \delta$ 168.2, $167.0($ each $\mathrm{C}=\mathrm{O}), 153.2\left(\mathrm{C}^{3,5}\right.$ of $\left.\mathrm{C}_{6} \mathrm{H}_{2}\right), 139.5\left(\mathrm{C}^{3}\right.$ of $\left.\mathrm{C}_{6} \mathrm{H}_{3}\right), 138.0\left(\mathrm{C}^{1}\right.$ of $\left.\mathrm{C}_{6} \mathrm{H}_{2}\right), 135.6\left(\mathrm{C}^{5}\right.$ of $\left.\mathrm{C}_{6} \mathrm{H}_{3}\right), 133.1$ $\left(\mathrm{C}^{1}\right.$ of $\left.\mathrm{C}_{6} \mathrm{H}_{3}\right), 126.3\left(\mathrm{C}^{4}\right.$ of $\left.\mathrm{C}_{6} \mathrm{H}_{2}\right), 120.9\left(\mathrm{C}^{4}\right.$ of $\left.\mathrm{C}_{6} \mathrm{H}_{3}\right)$, $116.5\left(\mathrm{C}^{6}\right.$ of $\left.\mathrm{C}_{6} \mathrm{H}_{3}\right), 115.9\left(\mathrm{C}^{2}\right.$ of $\left.\mathrm{C}_{6} \mathrm{H}_{3}\right), 105.5\left(\mathrm{C}^{2,6}\right.$ of $\left.\mathrm{C}_{6} \mathrm{H}_{2}\right)$, $73.5\left(4-\mathrm{OCH}_{2}\right), 69.2\left(3,5-\mathrm{OCH}_{2}\right), 31.9,31.9,30.4,29.8,29.7$, 29.7, 29.7, 29.6, 29.4, 29.4, 29.4, 29.3, 26.1, 26.1, 22.7 (each $\left.\mathrm{CH}_{2}\right), 14.1\left(\mathrm{CH}_{3}\right)$. IR (ATR): 3293, 2922, 2853, 1763, 1712, 1701, 1616, 1597, 1537, 1508, 1475, 1443, 1409, 1390, 1332, $1296,1243,1171,1123,1039,876,827,810,736 \mathrm{~cm}^{-1}$. MALDI-TOF-MS calcd for $\left[\mathrm{M}^{+}:\right.$: 1564.22. Found: 1565.26 $\left([\mathrm{M}+\mathrm{H}]^{+}\right)$. Anal. Calcd for $\mathrm{C}_{100} \mathrm{H}_{161} \mathrm{~N}_{3} \mathrm{O}_{10}: \mathrm{C}, 76.73 ; \mathrm{H}$, 10.37; N, 2.68. Found: C, 76.98; H, 10.38; N, 2.52.

4.1.6. PAP trimer 4c. A Schlenk tube equipped with a stirbar was charged with 12c $(68.0 \mathrm{mg}, 80.5 \mu \mathrm{mol}), 9 c(140 \mathrm{mg}$, $177 \mu \mathrm{mol}), \quad \mathrm{Pd}(\mathrm{OAc})_{2} \quad(0.18 \mathrm{mg}, \quad 0.80 \mu \mathrm{mol}), \quad \mathrm{XPhos}$ $(0.80 \mathrm{mg}, 1.7 \mu \mathrm{mol})$, and $\mathrm{K}_{3} \mathrm{PO}_{4}(51.0 \mathrm{mg}, 240 \mu \mathrm{mol})$. The system was evacuated and backfilled with argon gas (this process was repeated three times), and then anhydrous toluene (3.2 mL) was added. The mixture was stirred at $100^{\circ} \mathrm{C}$ for $24 \mathrm{~h}$. The resulting orange suspension was cooled to room temperature and then the solvent was removed by pumping to give an orange oil, which was purified by flash column chromatography on silica gel eluted with $\mathrm{CH}_{2} \mathrm{Cl}_{2} /$ hexane (3/2) to give $\mathbf{4 c}$ as an orange sticky solid (182 $\mathrm{mg}, 97 \%$ yield). ${ }^{1} \mathrm{H} \mathrm{NMR}\left(\mathrm{CDCl}_{3}\right): \delta 9.85(\mathrm{~s}, 2 \mathrm{H}, \mathrm{NH}), 7.83\left(\mathrm{~s}, 2 \mathrm{H}, \mathrm{C}_{6} \mathrm{H}_{2}\right.$ (inner phthalimide)), $7.75\left(\mathrm{~d}, J=8.4 \mathrm{~Hz}, 2 \mathrm{H}, \mathrm{H}^{4}\right.$ of $\mathrm{C}_{6} \mathrm{H}_{3}$ (outer phthalimide)), 7.67 (apparent $\mathrm{t}, J=7.9 \mathrm{~Hz}, 2 \mathrm{H}, \mathrm{H}^{5}$ of $\mathrm{C}_{6} \mathrm{H}_{3}$ (outer phthalimide)), $7.49\left(\mathrm{~d}, J=7.3 \mathrm{~Hz}, 2 \mathrm{H}, \mathrm{H}^{6}\right.$ of $\mathrm{C}_{6} \mathrm{H}_{3}$ (outer phthalimide)), $6.60\left(\mathrm{~s}, 4 \mathrm{H}\right.$, outer $\left.\mathrm{C}_{6} \mathrm{H}_{2}(\mathrm{OR})_{3}\right), 6.58$ $\left(\mathrm{s}, 2 \mathrm{H}\right.$, inner $\left.\mathrm{C}_{6} \mathrm{H}_{2}(\mathrm{OR})_{3}\right), 3.98-3.92\left(\mathrm{~m}, 18 \mathrm{H}, \mathrm{OCH}_{2}\right)$, $1.82-1.70,1.52-1.10$ (each $\left.\mathrm{m}, 180 \mathrm{H}, \mathrm{CH}_{2}\right), 0.92-0.82(\mathrm{~m}$, $\left.27 \mathrm{H}, \mathrm{CH}_{3}\right) .{ }^{13} \mathrm{C}\left\{{ }^{1} \mathrm{H}\right\} \mathrm{NMR}\left(\mathrm{CDCl}_{3}\right): \delta$ 168.4, 167.4, 167.1 (each $\mathrm{C}=\mathrm{O}), 153.3\left(\mathrm{C}^{3,5}\right.$ of $\left.\mathrm{C}_{6} \mathrm{H}_{2}(\mathrm{OR})_{3}\right), 140.1\left(\mathrm{C}^{3}\right.$ of $\mathrm{C}_{6} \mathrm{H}_{3}$ (outer phthalimide)), $138.1\left(\mathrm{C}^{1}\right.$ of inner $\left.\mathrm{C}_{6} \mathrm{H}_{2}(\mathrm{OR})_{3}\right)$, $138.1\left(\mathrm{C}^{1}\right.$ of outer $\left.\mathrm{C}_{6} \mathrm{H}_{2}(\mathrm{OR})_{3}\right), 135.7\left(\mathrm{C}^{5}\right.$ of $\mathrm{C}_{6} \mathrm{H}_{3}$ (outer phthalimide) $), 133.5\left(\mathrm{C}^{3,6}\right.$ of $\mathrm{C}_{6} \mathrm{H}_{2}$ (inner phthalimide)), 133.2 ( $\mathrm{C}^{1}$ of $\mathrm{C}_{6} \mathrm{H}_{3}$ (outer phthalimide) $), 126.3\left(\mathrm{C}^{4}\right.$ of outer $\left.\mathrm{C}_{6} \mathrm{H}_{2}(\mathrm{OR})_{3}\right), 126.0\left(\mathrm{C}^{4}\right.$ of inner $\left.\mathrm{C}_{6} \mathrm{H}_{2}(\mathrm{OR})_{3}\right), 124.0\left(\mathrm{C}^{4,5}\right.$ of $\mathrm{C}_{6} \mathrm{H}_{2}$ (inner phthalimide) ), $120.0\left(\mathrm{C}^{4}\right.$ of $\mathrm{C}_{6} \mathrm{H}_{3}$ (outer phthalimide $)$ ), 116.8 ( $\mathrm{C}^{6}$ of $\mathrm{C}_{6} \mathrm{H}_{3}$ (outer phthalimide $)$ ), $116.0\left(\mathrm{C}^{2}\right.$ of $\mathrm{C}_{6} \mathrm{H}_{3}$ (outer phthalimide) $), 115.2\left(\mathrm{C}^{1,2}\right.$ of $\mathrm{C}_{6} \mathrm{H}_{2}$ (inner phthalimide $)$ ), $105.6\left(\mathrm{C}^{2,6}\right.$ of inner $\left.\mathrm{C}_{6} \mathrm{H}_{2}(\mathrm{OR})_{3}\right), 105.5\left(\mathrm{C}^{2,6}\right.$ of outer $\left.\mathrm{C}_{6} \mathrm{H}_{2}(\mathrm{OR})_{3}\right), 73.5\left(4-\mathrm{OCH}_{2}\right), 69.2\left(3,5-\mathrm{OCH}_{2}\right), 32.0,31.9$, $30.4,29.8,29.7,29.7,29.4,29.4,29.4,29.3,26.2,26.1$, 22.7 (each $\left.\mathrm{CH}_{2}\right), 14.1\left(\mathrm{CH}_{3}\right)$. IR (ATR): 2922, 2853, 1768, 1747, 1706, 1619, 1597, 1506, 1471, 1442, 1409, 1390, 1298, 1233, 1173, 1120, 875, $739 \mathrm{~cm}^{-1}$. MALDI-TOF-MS calcd for $\left[\mathrm{M}^{+}\right.$: 2352.82. Found: $2353.72\left([\mathrm{M}+\mathrm{H}]^{+}\right)$. Anal. Calcd for $\mathrm{C}_{150} \mathrm{H}_{241} \mathrm{~N}_{5} \mathrm{O}_{15}$ : C, 76.52; H, 10.32; N, 2.97. Found: $76.71 ; \mathrm{H}, 10.42 ; \mathrm{N}, 2.97$.

\subsection{Two dimensional NMR}

All two dimensional NMR spectra were recorded on a $500 \mathrm{MHz}$ NMR (Varian Unity Inova) by means of a
$5 \mathrm{~mm} \mathrm{1H/X} \mathrm{Inverse} \mathrm{Detection} \mathrm{probe} \mathrm{equipped} \mathrm{with} \mathrm{gradient}$ capabilities at $298 \mathrm{~K}$. Deuterated chloroform was deacidified and dried by passing it through a column of activated basic alumina (type I). Solutions used for NOE measurements were degassed by a repetitive freeze-pumpthaw procedure. For all measurements the $90^{\circ}{ }^{1} \mathrm{H}$ pulse width was calibrated $(4.8 \mu \mathrm{s}$ at a transmitter power of $59 \mathrm{~dB})$. The compression factor of the amplifier, needed for ZQ suppression, was calculated from the $90^{\circ}$ pulse width at a transmitter power of $53 \mathrm{~dB}$ and was determined to be 0.9 . Volume integrals were determined in VNMR using the $112 \mathrm{~d}$ routine.

2D NOESY experiments were performed with a relaxation delay time of $3 \mathrm{~s}$ and a mixing time of $100 \mathrm{~ms}$. Zero quantum artifacts were removed by swept-pulse/gradient pairs. ${ }^{55}$ All 2D-data were collected in the phase-sensitive mode using the States-Haberkorn method. A total of 400 FIDs of $2 \mathrm{~K}$ complex data points were collected in $\mathrm{t} 2$ with 16 scans per increment and zero-filling was applied in both dimensions before Fourier transformation. These data was then processed with a cosine squared window function in both dimensions.

\subsection{Computational procedure}

The hybrid of Becke's non-local three parameter exchange functional with the Lee-Yang-Parr gradient-corrected correlation functional (B3LYP) was used with the 6-311G(d,p) basis set for calculating gas phase optimized geometries and relative energies. The optimized geometry at the B3LYP/6-311G(d,p) level was used as initial geometry for a calculation at the B3LYP/6-311+G(d,p) level of theory. Analytical frequency computation on the optimized geometries revealed only real frequencies, indicating that the optimized geometries are true local minima. Relative stabilities include the zero-point energy (ZPE), calculated with the same method from the unscaled harmonic B3LYP frequencies. Energies reported are differences in Gibbs free energy at $298.15 \mathrm{~K}$ and a pressure of $1 \mathrm{~atm}$. All computations were performed using the GAUSSIAN $03^{56}$ package. Geometry optimization was performed using the Berny algorithm and normal convergence criteria were used (rms force criterion $3 \times 10^{-4}$ ). All geometries were optimized without symmetry constraints. An analytical Hessian was computed at the initial point of the optimization using the $o p t=c a l c f c$ keyword. The size of the integration grid was set to default (pruned $(75,302)$ grid). The stability of the final wave function was tested by using the stable keyword, available in the GAUSSIAN 03 package. In all cases the restricted wave function did not contain any singlet instabilities.

\section{Acknowledgements}

We are grateful to Mr. Joost van Dongen, Mr. Ralf Bovee, and Dr. Xianwen Lou for technical assistance. Dr. Christian Nielsen and Prof. Dr. René Jansen are acknowledged for helpful discussions on the DFT calculations and critical reading of the document. This work is supported by the Council for Chemical Sciences of The Netherlands Organization for Scientific Research (CW-NWO). 


\section{Supplementary data}

Detailed experimental procedures and the characterization of each compound. 2D COSY, TOCSY, HMQC, and NOESY spectra for compound 4c. B3LYP/6-311G(d,p) optimized geometries, B3LYP/6-311 $\mathrm{G}^{+}(\mathrm{d}, \mathrm{p})$ optimized geometries, frequency calculations, the energies of the corresponding conformers of syn and anti PUP and PAP dimers, and comparison of calculated geometries with the crystal structures. Crystal structures of $\mathbf{3 a}, \mathbf{3 b}$, and $\mathbf{2 0 a}$ as cif files. Supplementary data associated with this article can be found in the online version, at doi:10.1016/j.tet.2007.04.002.

\section{References and notes}

1. For reviews on biotic and abiotic helical structures, see: (a) Gellman, S. H. Acc. Chem. Res. 1998, 31, 173; (b) Schmuck, C. Angew. Chem., Int. Ed. 2003, 42, 2448; (c) Nakano, T.; Okamoto, Y. Chem. Rev. 2001, 101, 4013; (d) Cubberley, M. S.; Iverson, B. L. Curr. Opin. Chem. Biol. 2001, 5, 650; (e) Cornelissen, J. J. L. M.; Rowan, A. E.; Nolte, R. J. M.; Sommerdijk, N. A. J. M. Chem. Rev. 2001, 101, 4039; (f) Nowick, J. S. Acc. Chem. Res. 1999, 32, 287; (g) Katz, T. J. Angew. Chem., Int. Ed. 2000, 39, 1921; (h) Sanford, A. R.; Yamato, K.; Yang, X.; Yuan, L.; Gong, B. Eur. J. Biochem. 2004, 271, 1416; (i) Gong, B. Chem.-Eur. J. 2001, 7, 4336; (j) Maeda, K.; Yashima, E. Top. Curr. Chem. 2006, 265, 47; (k) Huc, I. Eur. J. Org. Chem. 2004, 1, 17; (1) Rowan, A. E.; Nolte, R. J. M. Angew. Chem., Int. Ed. 1998, 37, 63; (m) Yashima, E.; Maeda, K.; Nishimura, T. Chem.-Eur. J. 2004, 10, 42; (n) Laarhoven, W. M.; Prinsen, W. J. C. Top. Curr. Chem. 1984, 125, 63; (o) Cheng, R. P.; Gellman, S. H.; DeGrado, W. F. Chem. Rev. 2001, 101, 3219; (p) Sanford, A. R.; Gong, B. Curr. Org. Chem. 2003, 7, 1649; (q) Licini, G.; Prins, L. J.; Scrimin, P. Eur. J. Org. Chem. 2005, 6, 969.

2. Hill, D. J.; Mio, M. J.; Prince, R. B.; Hughes, T. S.; Moore, J. S. Chem. Rev. 2001, 101, 3893.

3. Corbin, P. S.; Zimmerman, S. C.; Thiessen, P. A.; Hawryluk, N. A.; Murray, T. J. J. Am. Chem. Soc. 2001, 123, 10475.

4. (a) Gillies, E. R.; Dolain, C.; Léger, J.-M.; Huc, I. J. Org. Chem. 2006, 71, 7931; (b) Dolain, C.; Léger, J.-M.; Delsuc, N.; Gornitzka, H.; Huc, I. Proc. Natl. Acad. Sci. U.S.A. 2005, 102, 16146; (c) Dolain, C.; Gérlard, A.; Laguerre, M.; Jiang, H.; Maurizot, V.; Huc, I. Chem.-Eur. J. 2005, 11, 6135; (d) Jiang, H.; Léger, J.-M.; Huc, I. J. Am. Chem. Soc. 2003, 125, 3448; (e) Dolain, C.; Maurizot, V.; Huc, I. Angew. Chem., Int. Ed. 2003, 42, 2738; (f) Huc, I.; Maurizot, V.; Gornitzka, H.; Leger, J. M. Chem. Commun. 2002, 578.

5. Hu, Z.-Q.; Hu, H.-Y.; Chen, C.-F. J. Org. Chem. 2006, 71, 1131.

6. (a) Berl, V.; Huc, I.; Khoury, R. G.; Krische, M. J.; Lehn, J. M. Nature 2000, 407, 720; (b) Berl, V.; Huc, I.; Khoury, R. G.; Lehn, J. M. Chem.-Eur. J. 2001, 7, 2798; (c) Berl, V.; Huc, I.; Khoury, R. G.; Lehn, J. M. Chem.-Eur. J. 2001, 7, 2810.

7. (a) Zhu, J.; Parra, R. D.; Zeng, H.; Skrzypczak-Jankun, E.; Zeng, X. C.; Gong, B. J. Am. Chem. Soc. 2000, 122, 4219; (b) Yang, X.; Martinovic, S.; Smith, R. D.; Gong, B. J. Am. Chem. Soc. 2003, 125, 9932; (c) Yuan, L.; Zeng, H.; Yamato, K.; Sanford, A. R.; Feng, W.; Atreya, H. S.; Sukumaran, D. K.; Szyperski, T.; Gong, B. J. Am. Chem. Soc. 2004, 126, 16528; (d) Yang, X.; Yuan, L.; Yamato, K.; Brown, A. L.; Feng, W.; Furukawa, M.; Zeng, X. C.; Gong, B. J. Am. Chem. Soc. 2004, 126, 3148; (e) Gong, B.; Zeng, H.; Zhu, J.; Yua, L.; Han, Y.; Cheng, S.; Furukawa, M.; Parra, R. D.;
Kovalevsky, A. Y.; Mills, J. L.; Skrzypczak-Jankun, E.; Martinovic, S.; Smith, R. D.; Zheng, C.; Szyperski, T.; Zeng, X. C. Proc. Natl. Acad. Sci. U.S.A. 2002, 99, 11583; (f) Zhang, A.; Han, Y.; Yamato, K.; Zeng, X. C.; Gong, B. Org. Lett. 2006, 8, 803.

8. (a) Hou, J.-L.; Shao, X.-B.; Chen, G.-J.; Zhou, Y.-X.; Jiang, X.-K.; Li, Z.-T. J. Am. Chem. Soc. 2004, 126, 12386; (b) Li, C.; Ren, S.-F.; Hou, J.-L.; Yi, H.-P.; Zhu, S.-Z.; Jiang, X.-K.; Li, Z.-T. Angew. Chem., Int. Ed. 2005, 44, 5725.

9. (a) Hamuro, Y.; Geib, S. J.; Hamilton, A. D. J. Am. Chem. Soc. 1997, 119, 10587; (b) Hamuro, Y.; Geib, S. J.; Hamilton, A. D. J. Am. Chem. Soc. 1996, 118, 7529.

10. (a) Nelson, J. C.; Saven, J. G.; Moore, J. S.; Wolynes, P. G. Science 1997, 277, 1793; (b) Zhao, D.; Moore, J. S. J. Am. Chem. Soc. 2002, 124, 9996; (c) Prince, R. B.; Saven, J. G.; Wolynes, P. G.; Moore, J. S. J. Am. Chem. Soc. 1999, 121, 3114; (d) Gin, M. S.; Yokozawa, T.; Prince, R. B.; Moore, J. S. J. Am. Chem. Soc. 1999, 121, 2643; (e) Stone, M. T.; Fox, J. M.; Moore, J. S. Org. Lett. 2004, 6, 3317; (f) Brunsveld, L.; Meijer, E. W.; Prince, R. B.; Moore, J. S. J. Am. Chem. Soc. 2001, 123, 7978.

11. (a) Wang, W.; Li, L.-S.; Helms, G.; Zhou, H.-H.; Li, A. D. Q. J. Am. Chem. Soc. 2003, 125, 1120; (b) Li, A. D. Q.; Wang, W.; Wang, L.-Q. Chem.-Eur. J. 2003, 9, 4594.

12. Hou, J.-L.; Jia, M.-X.; Jiang, X.-K.; Li, Z.-T.; Chen, G.-J. J. Org. Chem. 2004, 69, 6228.

13. Masu, H.; Sakai, M.; Kishikawa, K.; Yamamoto, M.; Yamaguchi, K.; Kohmoto, S. J. Org. Chem. 2005, 70, 1423.

14. (a) Jones, T. V.; Blatchly, R. A.; Tew, G. N. Org. Lett. 2003 , 5, 3297; (b) Jones, T. V.; Slutsky, M. M.; Laos, R.; de Greef, T. F. A.; Tew, G. N. J. Am. Chem. Soc. 2005, 127, 17235.

15. (a) Lokey, R. S.; Iverson, B. L. Nature 1995, 275, 303; (b) Nguyen, J. Q.; Iverson, B. L. J. Am. Chem. Soc. 1999, 121, 2639; (c) Zych, A. J.; Iverson, B. L. J. Am. Chem. Soc. 2000, 122, 8898; (d) Gabriel, G. J.; Iverson, B. L. J. Am. Chem. Soc. 2002, 124, 15174; (e) Gabriel, G. J.; Sorey, S.; Iverson, B. L. J. Am. Chem. Soc. 2005, 127, 2637.

16. Zhao, X.; Jia, M.-X.; Jiang, X.-K.; Wu, L.-Z.; Li, Z.-T.; Chen, G.-J. J. Org. Chem. 2004, 69, 270.

17. Cuccia, L. A.; Lehn, J. M.; Homo, J. C.; Schmutz, M. Angew. Chem., Int. Ed. 2000, 39, 233.

18. Chang, K.-J.; Kang, B.-J.; Lee, M.-H.; Jeong, K.-S. J. Am. Chem. Soc. 2005, 127, 12214.

19. For recent examples on cooperative transitions in supramolecular systems based on the nucleation-elongation model, see: (a) Wackerly, J. W.; Moore, J. S. Macromolecules 2006, 39, 7269; (b) Zhao, D.; Moore, J. S. Org. Biomol. Chem. 2003, 1, 3471; (c) Jonkheijm, P.; van der Schoot, P.; Schenning, A. P. H. J.; Meijer, E. W. Science 2006, 313, 80.

20. For selected examples, see: (a) Ferrer, M.; Kapoor, T. M.; Strassmaier, T.; Weissenhorn, W.; Skehel, J. J.; Oprian, D.; Schreiber, S. L.; Wiley, D. C.; Harrison, S. C. Nat. Struct. Biol. 1999, 6, 953; (b) Stephens, O. M.; Kim, S.; Welch, B. D.; Hodsdon, M. E.; Kay, M. S.; Schepartz, A. J. Am. Chem. Soc. 2005, 127, 13126; (c) Sadowsky, J. D.; Fairlie, W. D.; Hadley, E. B.; Lee, H.-S.; Umezawa, N.; NikolovskaColeska, Z.; Wang, S.; Huang, D. C. S.; Tomita, Y.; Gellman, S. H. J. Am. Chem. Soc. 2007, 129, 139.

21. For selected examples, see: (a) Schmitt, M. A.; Weisblum, B.; Gellman, S. H. J. Am. Chem. Soc. 2004, 126, 6848; (b) Liu, D.; Choi, S.; Chen, B.; Doerksen, R. J.; Clements, D. J.; Winkler, J. D.; Klein, M. L.; DeGrado, W. F. Angew. Chem., Int. Ed. 2004, 43, 1158; (c) Ishitsuka, Y.; Arnt, L.; Majewski, J.; 
Frey, S.; Ratajczek, M.; Kjaer, K.; Tew, G. N.; Lee, K. Y. C. J. Am. Chem. Soc. 2006, 128, 13123; (d) Arnt, L.; Rennie, J. R.; Linser, S.; Willumeit, R.; Tew, G. N. J. Phys. Chem. B 2006, 110, 3527.

22. Choi, S.; Clements, D. J.; Pophristic, V.; Ivanov, I.; Vemparala, S.; Bennet, J. S.; Klein, M. L.; Winkler, J. D.; DeGrado, W. F. Angew. Chem., Int. Ed. 2005, 44, 2.

23. Zhao, Y.; Zhong, Z. J. Am. Chem. Soc. 2005, 127, 17894.

24. Han, J. J.; Wang, W.; Li, A. D. Q. J. Am. Chem. Soc. 2006, $128,672$.

25. van Gorp, J. J.; Vekemans, J. A. J. M.; Meijer, E. W. Chem. Commun. 2004, 60.

26. Sinkeldam, R. W.; van Houtem, M. H. C. J.; Koeckelberghs, G.; Vekemans, J. A. J. M.; Meijer, E. W. Org. Lett. 2006, 8, 383.

27. Sinkeldam, R. W.; van Houtem, M. H. C. J.; Pieterse, K.; Vekemans, J. A. J. M.; Meijer, E. W. Chem.-Eur. J. 2006, 12, 6129.

28. (a) Prince, R. B.; Brunsveld, L.; Meijer, E. W.; Moore, J. S. Angew. Chem., Int. Ed. 2000, 39, 228; (b) Green, M. M.; Peterson, N. C.; Sata, A.; Teramoto, A.; Cook, R.; Lifson, S. Science 1995, 268, 1860.

29. For an excellent discussion on the influence of configurational entropy on the nature of the free energy landscape of protein folding, see: Dinner, A. D.; Smith, L. J.; Dobson, C. M.; Karplus, M. Trends Biochem. Sci. 2000, 25, 331.

30. (a) Nakajima, T.; Kawagoe, T. Synth. Met. 1989, 28, 629; (b) Bergeron, J.-Y.; Dao, L. H. Macromolecules 1992, 25, 3332; (c) Kitani, A.; Kaya, M.; Sakaki, K. J. Electrochem. Soc. 1986, 133, 1069; (d) MacDiarmid, A. G.; Yang, L. S.; Huang, W. S.; Humphrey, B. D. Synth. Met. 1987, 18, 393; (e) Gustafsson, G.; Cao, Y.; Treacy, G. M.; Klavetter, F.; Colaneri, N.; Heeger, A. G. Nature 1992, 356, 47; (f) DeBerry, D. J. Electrochem. Soc. 1985, 132, 1022; (g) Genies, E. M.; Lapkowski, M.; Santier, C.; Vieil, E. Synth. Met. 1987, 18, 631; (h) Nguyen, M. T.; Dao, L. H. J. Electrochem. Soc. 1989, 136, 2131; (i) Paul, E. W.; Ricco, A. J.; Wrighton, M. S. J. Phys. Chem. 1985, 89, 1441; (j) Nagaoka, T.; Kakuno, K.; Fujimoto, M.; Nakao, H.; Yano, J.; Ogura, K. J. Electroanal. Chem. 1994, 368, 315; (k) Alcacer, L. Conducting Polymers; Reidel Publishing Company: Holland, 1987.

31. (a) Havinga, E. E.; ten Hoeve, W.; Wynberg, H. Polym. Bull. 1992, 29, 119; (b) Havinga, E. E.; ten Hoeve, W.; Wynberg, H. Synth. Met. 1993, 55, 299; (c) Karikomi, M.; Kitamura, C.; Tanaka, S.; Yamashita, Y. J. Am. Chem. Soc. 1995, 117, 6791; (d) Kitamura, C.; Tanaka, S.; Yamashita, Y. Chem. Mater. 1996, 8, 570.

32. Muci, A. R.; Buchwald, S. L. Top. Curr. Chem. 2002, $219,131$.

33. Hartwig, J. F. Handbook of Organopalladium Chemistry for Organic Synthesis; Negishi, E. I., Ed.; Wiley-Interscience: New York, NY, 2002; Vol. 1, p 1051.

34. Hennessy, E. J.; Buchwald, S. L. J. Org. Chem. 2005, 70, 7371.

35. Dierschke, F.; Jacob, J.; Müllen, K. Synth. Met. 2006, 156, 433.

36. Biniecki, S.; Moll, M.; Rylski, L. Ann. Pharm. Fr. 1958, 421.

37. Kolyamsin, O. A.; Vasil'eva, S. Y.; Kol'tsov, N. I. Russ. J. Org. Chem. 2001, 37, 1614.

38. O’Donovan, A. R. M.; Shepherd, M. K. Tetrahedron Lett. 1994, $35,4425$.

39. Katayama, H.; Greef, T. F. A.; Vekemans, J. A. J. M.; Meijer, E. W. Unpublished results.

40. The intensities of the off-diagonal correlations were rated on a relative scale by calculation of the relative volume integral of the cross peak with respect to the diagonal intensity of $\mathrm{H}_{\alpha^{\prime}}$ (which was set to 1): $\mathrm{H}_{\alpha^{\prime}}-\mathrm{H}_{\alpha}=0.03, \mathrm{NH}-\mathrm{H}_{\alpha^{\prime}}=0.002$. This normalization is valid due to the fact that the $\mathrm{NH}$ diagonal peak is very close to $1(0.99)$.

41. Sakurai, H.; Ritonga, M. T. S.; Shibatani, H.; Hirao, T. J. Org. Chem. 2005, 70, 2754.

42. Kohn, W.; Sham, L. J. Phys. Rev. 1965, 140, A1133.

43. Sahu, P. K.; Mishra, R. K.; Lee, S.-L. J. Phys. Chem. A 2005 , 109, 2887.

44. (a) Guo, D.; Sijbesma, R. P.; Zuilhof, H. Org. Lett. 2004, 21, 3667; (b) Lukin, O.; Leszczynski, J. J. Phys. Chem. A 2002, 106, 6775 .

45. Tang, H.; Doerksen, R. J.; Jones, T. V.; Klein, M. L.; Tew, G. N. Chem. Biol. 2006, 13, 427.

46. (a) Becke, A. D. Phys. Rev. 1988, A38, 3098; (b) Becke, A. D. J. Chem. Phys. 1993, 98, 5648; (c) Becke, A. D. J. Chem. Phys. 1997, 107, 8554; (d) Schmider, H. L.; Becke, A. D. J. Chem. Phys. 1998, 108, 9624; (e) Lee, C.; Yang, W.; Parr, R. G. Phys. Rev. B 1988, 37, 785.

47. Krishnan, R.; Binkley, J. S.; Seeger, R.; Pople, J. A. J. Chem. Phys. 1980, 72, 650.

48. Hariharan, P. C.; Pople, J. A. Theor. Chim. Acta 1973, 28, 213.

49. Chandrasekhar, J.; Andrade, J. G.; Schleyer, P. v. R. J. Am. Chem. Soc. 1981, 103, 5609.

50. (a) Novoa, J. J.; Sosa, C. J. Phys. Chem. 1995, 99, 15837; (b) Lee, C.; Fitzgerald, G.; Planas, M.; Novoa, J. J. J. Phys. Chem. 1996, 100, 7398; (c) Lee, C.; Sosa, C.; Planas, M.; Novoa, J. J. J. Chem. Phys. 1996, 104, 7081; (d) Sim, F.; St-Amant, A.; Papai, I.; Salahub, D. R. J. Am. Chem. Soc. 1992, 114, 4391; (e) Bertran, J.; Oliva, A.; RodriguezSantiago, L.; Sodupe, M. J. Am. Chem. Soc. 1998, 120, 8159; (f) van der Wijst, T.; Guerra, C. F.; Swart, M.; Bickelhaupt, F. M. Chem. Phys. Lett. 2006, 426, 415.

51. (a) Kristyan, S.; Pulay, P. Chem. Phys. Lett. 1994, 229, 175; (b) Hobza, P.; Sponer, J.; Reschel, T. J. Comput. Chem. 1995, $16,1315$.

52. Steiner, T.; Majerz, I.; Wilson, C. C. Angew. Chem., Int. Ed. 2001, 40, 2651.

53. At the MP2 level it was found that the transoid conformer of phenylurea was more stable than the cisoid conformer while at the B3LYP level the cisoid conformer is the global minimum. However, examination of the Cambridge Structural Database resulted in only one example of a transoid form while the cisoid form predominates. See: Bryantsev, V. S.; Firman, T. K.; Hay, B. P. J. Phys. Chem. A 2005, 109, 832.

54. Guerra, C. F.; Bickelhaupt, F. M.; Snijders, J. G.; Baerends, E. J. J. Am. Chem. Soc. 2000, 122, 4117.

55. Thrippleton, M. J.; Keeler, J. Angew. Chem., Int. Ed. 2003, 42, 3938.

56. Frisch, M. J.; Trucks, G. W.; Schlegel, H. B.; Scuseria, G. E.; Robb, M. A.; Cheeseman, J. R.; Zakrzewski, V. G.; Montgomery, J. A., Jr.; Stratmann, R. E.; Burant, J. C.; Dapprich, S.; Millam, J. M.; Daniels, A. D.; Kudin, K. N.; Strain, M. C.; Farkas, O.; Tomasi, J.; Barone, V.; Cossi, M.; Cammi, R.; Mennucci, B.; Pomelli, C.; Adamo, C.; Clifford, S.; Ochterski, J.; Petersson, G. A.; Ayala, P. Y.; Cui, Q.; Morokuma, K.; Malick, D. K.; Rabuck, A. D.; Raghavachari, K.; Foresman, J. B.; Cioslowski, J.; Ortiz, J. V.; Stefanov, B. B.; Liu, G.; Liashenko, A.; Piskorz, P.; Komaromi, I.; Gomperts, R.; Martin, R. L.; Fox, D. J.; Keith, T.; Al-Laham, M. A.; Peng, C. Y.; Nanayakkara, A.; Gonzalez, C.; Challacombe, M.; Gill, P. M. W.; Johnson, B. G.; Chen, W.; Wong, M. W.; Andres, J. L.; Head-Gordon, M.; Replogle, E. S.; Pople, J. A. Gaussian 03, Revision B.04; Gaussian: Wallingford, CT, 2003. 